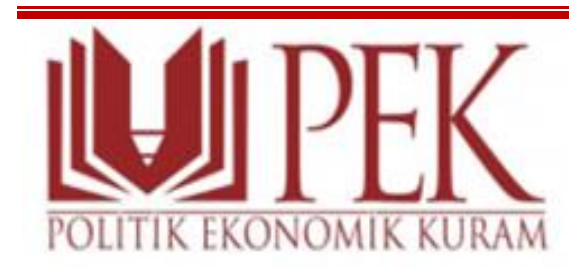

2021, Cilt 5, Sayı 1, 132-160

\section{POLITIKK EKONOMIK KURAM}

E-ISSN: 2587-2567

https://dergipark.org.tr/tr/pub/pek

Doi: $10.30586 /$ pek.943297

Makale Geliş Tarihi: 26.05.2021

Makale Kabul Tarihi: 13.06.2021

Araştırma Makalesi

\title{
Stajyer Öğrencilerin Emek Süreçleri: Meslek Liseleri Üzerine Niteliksel Bir Araştırma
}

\section{Labour Processes of Internship Students: A Qualitative Research on Vocational High Schools}

Sebiha KABLAY ${ }^{1}$

$\ddot{O ̈ z}$

Staj, meslek liselerinde öğrencilerin becerisini arttırmak amacıyla yapılan bir eğitim türüdür. Staj süreci, bazı okul tiplerinde öğrencilerin haklar açısından değil ama iş görme açısından işçileşmesine neden olmaktadır. Bu çalışmada, meslek lisesi öğrencilerinin staj süreçleri incelenmiştir. Bu amaçla 12 meslek lisesi mezunu, 8 de meslek lisesi öğretmeni olmak üzere toplam 20 katılımcıyla derinlemesine görüşmeler yapılmıştır. Bu araştırmanın sonucunda bazı okul tiplerinde öğrencilerin ve velilerin okulu öğrencinin bir meslek öğrenmesi ve işe girmesi için tercih ettiğ bulunmuştur. Ancak diğer meslek lisesi okullarının tercihinde genellikle öğrencinin yerleştirme sınavından düşük puan alması etkili olmaktadır. Temel amaç öğrencinin lise diploması almasıdır. Öğrencinin bir meslek edinmesi amacı bulunmamaktadır. Diğer bir sonuç ise öğrencilerin staj sürecinin okul türüne göre farklılaşmasıdır. Öğrencilerin staj süreleri, zamanları, staj yapılacak kurumun bulunması, staj kontrolleri, stajda yapılan işler farklılaşmaktadır. Bazı okul türlerinde staj sürecindeki öğrencinin bir işçi gibi çalışması söz konusudur. Diğer bazı okul türlerinde ise staj geçilmesi gereken bir ders türüdür. Mesleki eğitim pahalı bir eğitim türü olup bu alanda çalışmak istemeyen öğrencilerin mesleki eğitime yönlendirilmesi ekonomik değildir. Öğrencilerin hayatını etkileyecek bu tercihte öğrencinin yetenek ve beklentilerinin ön planda olması gerekmektedir.

Anahtar Kelimeler: Stajyer, meslek lisesi, mesleki eğitim, stajyer emeği.

Jel Kodlari: J240, J620, J440

Abstract

Internship is a type of education that aims to increase the skills of students in vocational high school. The intership process causes students to be laboring force in some types of school not in terms of rights but in terms of working. In this study, the internship processes of vocational high school students were examined. For this purpose, a quanlitative study was conducted with a total of 20 participants, including 12 vocational high school graduates and 8 vocational high school teachers. As a result of this study, it was found that in some school types, students and parents preferred the school for the student to learn a vocation and get a job. However, the student's low score in the placement exam is generally effective in the choosing other vocational high schools. Student' getting a high school diploma is the main purpose. There is no aim of the student acquire a profession. Another result is that the internship process of the students differs according to the type of school. Students' internship periods, times, finding the institution, internship checks, Works to be done during internship process are different. In some school types, the student in the internship process works like a worker. In some other school types, internship is a type of course that must be passed. Vocational education is an expensive type od education and it is not economical to direct students to vocational education who don't want to work in this field. Students' abilities and expectations should be at the forefront in this choice, which will affect the lives of the students.

Keywords: Internship, vocational high school, vocational education, internship labour.

Jel Codes: J240, J620, J440

\footnotetext{
${ }^{1}$ Doç. Dr., Ordu Üniversitesi Ünye iïBF Çalışma Ekonomisi ve Endüstri ilişkileri Bölümü, sebihakablay@odu.edu.tr.
} ORCID ID:0000-0003-1292-684X 


\section{Giriş}

Meslek edinmek belki de eğitimin en önemli sebepleri arasında gelmektedir. Özellikle düşük gelirli aileler için çocuğunun bir meslek sahibi olması ve kısa sürede iş edinerek gelir getirici bir işte çalışması hem "kendi hayatını kurtarması" hem de aileye destek olması açısından büyük önem arz etmektedir. Bu nedenle aileler çocuklarını küçük yaşlarda mesleki eğitim alabilecekleri kuruluşlara yerleştirmektedirler. Bazen ailelerin yoksulluğu, bazen babanın çalışmaya zorlaması veya yaşanılan yerde başka eğitim olanağının olmaması mesleki eğitimin (çıraklık ya da meslek lisesi öğrencisi) bir gerekçesi olmaktadır (Erder ve Lordoğlu, 1993: 69). Diğer yandan mesleki eğitim, devlet-sermaye ilişkilerinin neoliberal politikalar çerçevesinde yeniden yapılandırılmasının da bir parçasıdır. Üretim ilişkilerinin değişimi ve küresel rekabet, işgücünün bu rekabet koşullarına uygun eğitilmesini, vasıflandırılmasını gerekli kılmaktadır. Bu çerçevede mesleki eğitime ilişkin yapılan düzenlemeler küresel rekabette pay sahibi olabilmek için gerekli görülmektedir (Pınar, 2017). Gelişmiş ülkeler arasında yer alması istenen Türkiye için elindeki en önemli kaynağın genç ve dinamik bir yapıya sahip olan insan gücü olduğu, mesleki eğitimin insan gücünün rekabette avantaj sağlamasında önemli olduğu, bu yapılırken öğrencilerin kişisel yeteneklerine göre yönlendirilmesi gerektiği ileri sürülmektedir (Bınıcı ve Arı, 2004).

Mesleki eğitim orta öğretimde çıraklık merkezlerinde ya da bilinen adıyla meslek liselerinde gerçekleştirilmektedir. Mesleğin öğrenilmesi öğrencilerin alacağı teorik eğitimin yanı sıra beceri eğitimi denilen öğrencilerin teoride öğrendiklerini uygulamaya aktardı̆̆ gerçekleşmektedir. "Staj genellikle öğrencilerin ĕgitimde edindikleri teorik bilgilerin dişında bir takım mesleki bilgi, görgü, beceri, tutum ve davranışları geliştirmeleri, çalışma hayatına alışmaları amacıyla yapılan ve eğitimi tamamlayan bir faaliyet” tir (Kablay, 2019: 15). Meslek liselerinde yapılan staj, lisenin türüne göre farklı sınıflarda başlamakta, kimi zaman sadece eğitimöğretim döneminde yapılırken kimi zaman da eğitim öğretimin olmadığı yaz döneminde gerçekleştirilmektedir. Öğrencinin not ortalamasında ve mezuniyetinde staj notu önemli yer tutmaktadır. Öğrencinin mesleğe ilişkin becerilerini geliştirmesi ve mezun olduktan sonra bu mesleği yapabilmesi için staj süreci büyük önem taşımaktadır. Bu nedenle bu sürecin iyi planlanması, öğrencilerin staj yapacă̆ı işletme veya kurumların iyi seçilmesi, öğrencinin staj sürecinde takibinin yapılması ve bu süreçte usta öğreticiler veya öğretmenler ya da işletme/kurum çalışanları tarafından iyi yetiştirilmesi gerekmektedir. Ayrıca öğrenciler işletme veya kurumlarda bir çalışma gerçekleştirdiği için onların haklarının gözetilmesi, risklere karşı korunması ve önlemlerin alınması sağlanmalı; fiziksel, ruhsal ve akademik gelişimlerine uygun olmayan bir staj süreci geçirmeleri engellenmelidir.

Staj sürecinde amaç; öğrencilerin örgün eğitimde edindikleri bilgiyi sahaya uygulanması ve seçtikleri mesleğin becerilerini kazanmak olup staj bir çalışma biçimi değildir ve stajyerler de işçi sayılmaz. İşçi olmamaları onların işçilerin sahip olduğu hak ve borçlara da sahip olmadığı anlamına gelir. Ancak bazı meslek lisesi türlerinde staj süreci beceri eğitiminin ötesinde bir mal ve hizmet üretme sürecine dönüşmektedir. Bu lise türlerine endüstri meslek liselerini, turizm ve otelcilik meslek liselerini ve sağlık meslek liselerini örnek olarak verebiliriz. Hatta okullardaki atölyelerde ya da okulların otel veya restoranlarında elde edilen gelir ciddi bir döner sermaye yaratmaktadır (Kablay, 2019). Örneğin; ülkemizde Covid-19 pandemisinin yaşandığ1 Mart 2020- Mayıs 2021 döneminde Millî Eğitim Bakanlığı (MEB) Okulları ağırlıklı olarak uzaktan eğitime devam etmiş olmasına karşın özellikle pandemi sürecinde gereksinimi artan "maske, eldiven, yüz siperliği, dezenfektan, tek kullanımlık önlük ve tulum" gibi malzemelerin üretiminde meslek liseleri büyük katkı sağlamıştır (Kablay, 2021: 24). Ayrıca MEB'in verilerine göre alt yapı açısından güçlü olan 
İstanbul, Ankara, İzmir, Bursa, Konya, Tekirdağ, Mersin, Muğla ve Hatay illerindeki meslek liselerinde AR-GE merkezleri kurulmuş çeşitli cihazların üretimi de yapılmıştır. Bu cihazlar; cerrahi maske cihazı, N95 maske cihazı, solunum cihazı, video laringoskop cihazı, hava filtrasyon cihazı, yoğun bakım yatağı, numune alma ünitesi gibi cihazlardır. Ekim 2020’ye kadar genellikle uzaktan eğitimin uygulandığı dönemde mesleki ve teknik liselerde 60 milyon cerrahi maske (adet), 6 milyon litre yüzey dezenfektanı, 1 milyon yüz koruyucu siperlik ve tek kullanımlık önlük/tulum, 800 bin litre el dezenfektanı, 35 bin tek kullanımlık çatal-bıçak, 30 bin litre kolonya, 15 bin de N95 maske üretilmiştir (MEB, 2020: 40, 43; Kablay, 2021).

Stajyerler aslında ister kamu kurumlarında isterse de özel işletmelerde çalışsın üretim sürecinin önemli elemanları haline gelmiştir. Kimi zaman işletmeler tarafından stajyer çalıştırmak iş̧i sayısını azaltmak anlamına gelmekte, işveren emek maliyetlerini düşürmektedir. Stajyerler eğitim amacıyla işletmelerde bulunduğundan ve asıl amaçları iş görmek olmadığından işverene maliyetleri düşüktür. İ̧veren stajyer yerine işçi istihdam ettiğinde daha fazla ücret ve sigorta primi ödemek, işçilerle kimi zaman toplu pazarlığa oturmak ve daha ileri haklar vermek zorunda kalacaktır (Kablay, 2018). Oysa stajyerler işçi olmadığından bu ödemeleri yapmak zorunda kalmadığ 1 gibi devletten çeşitli teşvik ödemeleri de almaktadır. Stajyerlerin ucuz işgücü olarak görülmesi aslında onları işçileştirmekte ve beraberinde bir sömürü de yaratmaktadır ${ }^{2}$. Meslek liselerinde düşük ücretle çalışabilecek "itaatkâr" işgücü olarak yetiştirilen gençler iş piyasası için yetiştirilmektedir (Aksoy, 2017: 77).

Bu çalışmada meslek liselerindeki staj süreçleri, öğrencilerin süreçte yaşadığı sorunlar yapılan bir alan araştırması verileri ile desteklenmektedir.

\section{Stajyer Kavramı}

Stajyer kavramı çeşitli şekillerde tanımlanmaktadır. Çelik vd. (2019: 94) kavramı "bir işyerinde yapılan işleri izleyerek bilgisini geliştirmek için işveren yanında çalışan kişi" olarak tanımlamaktadırlar. Stajyer kavramı bir mesleğe ilişkin teorik bilgisi olan ancak bu bilgiyi geliştirmek için alanda pratik çalışmada bulunan kişiler için kullanılmaktadır (Kablay; 2019). Stajyerler hakkında 3008 sayılı Mesleki Eğitim Kanunu³ (MEK) hükümleri uygulanır. Stajyerler işçi sayılmadığından 4857 sayılı İş Kanunu ${ }^{4}$ ve 6098 sayılı Türk Borçlar Kanunu'nun ${ }^{5}$ iş̧̧ilere uygulanan hükümlerine tabi değildirler. MEK staj1 "Yükseköğretim Kurulunca, yükseköğretim kurumlarında verilmekte olan her düzeydeki alana özgü olarak belirlenen teorik ve uygulamalı dersler dışında, öğrencilerin ögrenim programlarıyla kazandırılması öngörülen mesleki bilgi, beceri, tutum ve davranışlarını geliştirmeleri, sektörü tanımaları, iş hayatına uyumları, gerçek üretim ve hizmet ortaminda yetişmeleri amacıyla işletmede yaptıkları mesleki çalışma" (MEK md. 3/1) olarak tanımlamaktadır6.

Yasa tanımda sadece yükseköğretim kurumlarındaki öğrencilerden stajyer olarak söz etse de orta öğretim kurumlarında beceri eğitimi çerçevesinde kurum ve işletmelerde yapılan çalışma da staj olarak kabul edilmektedir. Mesleki ve teknik liselerde öğrenciler gönüllü ya da zorunlu staj uygulamasına katılmaktadırlar. MEK "mesleki ve teknik eğitim okul ve kurumları öğrencilerinin beceri eğitimlerini işletmelerde, teorik eğitimlerini ise mesleki ve teknik eğitim okul ve

\footnotetext{
2 Stajyerlerin işçileşme süreci için Kablay'ın (2019) “Stajyer mi İşçi mi?” adlı makalesine bakılabilir.

${ }^{3}$ Kabul tarihi 05/6/1986, 19/06/1986 tarih ve 19139 sayılı Resmî Gazete.

${ }^{4}$ Kabul tarihi 22/5/2003, 10/6/2003 tarih ve 25134 say1lı Resmî Gazete.

${ }^{5}$ Kabul tarihi 11/01/2011, 04/02/2011 tarih ve 27836 sayılı Resmî Gazete.

${ }^{6} \mathrm{Bu}$ çalışmada Yükseköğretim Kurumlarındaki staj süreci konu edinilmemektedir.
} 
kurumlarında veya işletme veya kurumlarca tesis edilen eğitim kurumlarında" yapılan eğitimi "İsletmelerde Mesleki Eğitim" olarak tanımlamaktadır (md.3/h). Bu öğrencilerin yaptıkları etkinlik de bir staj uygulamasıdır. Çünkü teorik bilgiyi okullarında almakta, sahaya ilişkin bilgi, beceri, tutum ve davranışlarını geliştirmek için ise işyerlerine uygulamaya çıkmaktadırlar. Diğer yandan bu uygulamaların çoğunluğu zorunlu olup mesleki eğitimin bir parçasıdır (Kablay, 2019).

Stajyerlik çıraklıktan farklıdır. Çıraklıkta bir meslek ya da sanatı öğrenmek ve vasıflı işçi olma amacı varken; stajyerler var olan mesleki bilgisini, uygulamaya katılarak işyerinde geliştirme amacı taşırlar (Süzek, 2019; Çelik vd. 2018). Aslında stajyerler, çıraklar ve iş̧̧iler bir işverenin (kamu ya da özel) işyerinde birlikte bulunurken hukuksal açıdan birbirlerinden farklılaşmaktadırlar. İşçilerin iş görme faaliyetinin amacı bu faaliyet karşıllı̆ında bir ücret edinmektir. Oysa stajyerler bu çalışmayı gelir elde etmek için değil, mesleğin gerektirdiği bilgi ve tecrübeyi arttırmak amacıyla yürütürler. İşveren ile kurdukları iş ilişkinde de stajyerinin yararı ön plandadır (Çelik vd., 2019; Kablay, 2019). Tablo 1 işçi ve stajyerler arasındaki temel farklılıkları göstermektedir.

Tablo 1: İşçi ve Stajyerlerin Yasal Durum Karşılaştırması

\begin{tabular}{|c|c|c|}
\hline ÖZELLIKKLER & İşÇİ & STAJYER \\
\hline Amaç & $\begin{array}{l}\text { İş görme } \\
\text { Mal ya da hizmet üretimi }\end{array}$ & $\begin{array}{l}\text { Eğitim ile bilgi, görgü, beceriyi arttırma } \\
\text { 10'dan fazla işçi çalıştıran yerde stajyer almak } \\
\text { zorunlu (iş̧̧i sayısının \% } \% \text { 'i) }\end{array}$ \\
\hline Sözleşme & İşs sözleşmesi & İş sözleşmesi ile çalışmaz \\
\hline Yasal Düzenleme & 4857 sayılı İş Kanunu & 3308 sayılı Meslek Eğitim Kanunu \\
\hline Ödeme & $\begin{array}{l}\text { Ücret } \\
\text { Asgari ücret }\end{array}$ & $\begin{array}{l}\text { Sosyal ücret } \\
\text { Asgari ücretin yüzde otuzu, bazı durumlarda yüzde } \\
\text { altmışı } \\
\text { Devlet desteği }=20 \text { 'den az işçi olan işyerinde } 2 / 3 \text {, } \\
20 \text { 'den fazla işçi varsa } 1 / 3 \text { ) }\end{array}$ \\
\hline Çalışma Süresi & $\begin{array}{l}\text { Tam zamanlı ya da kısmi } \\
\text { zamanlı }\end{array}$ & $\begin{array}{l}\text { Okul döneminde haftada 2-3 gün } \\
\text { Yaz döneminde } 36 / 40 \text { iş günü ya da } \\
\text { 4,5- } 6 \text { ay }\end{array}$ \\
\hline Sosyal Güvence & $\begin{array}{l}\text { Uzun vadeli sigorta kolları } \\
\text { Kısa vadeli sigorta kolları } \\
\text { GSS }\end{array}$ & $\begin{array}{l}\text { Kısmi sigortalılar } \\
\text { IKMMH Sigortas1, GSS (Primler asgari ücretin } \\
\% 50 \text { 'si üzerinden ödeniyor) }\end{array}$ \\
\hline
\end{tabular}


Kaynak: Kablay (2019: 18).

Yasaya göre on ve daha fazla personel çalıştıran işletmelerin, personel sayısının yüzde beşinden az olmayacak şekilde "mesleki ve teknik eğitim okul ve kurumu ögrencilerine staj ve tamamlayıcl eğitim yaptırır... Mesleki eğitim kapsamına alınıp alınmadı̆̆ına bakılmaksızın ondan az personel çallşstıran işletmeler de mesleki ve teknik eğitim okul ve kurumları öğrencilerine ...beceri eğitimi, staj ve tamamlayıcı eğitim yaptırır". Personel sayısının belirlenmesinde Ocak ayı, mevsimlik işlerin yapıldığı işletmelerde ise Temmuz ayı personel sayısı dikkate alınır (MEK md.18). 2010 yılından sonra genel liseler Anadolu Lisesine dönüştürülmüş ve yapılan Liselere Geçiş Sınavı ile ortaöğretimdeki mesleki ve teknik liselerin ${ }^{7}$ sayısı arttırılmıştır. Genel liselerin sayısının azaltılması sınavda daha düşük puan alan öğrencileri meslek liselerine ve açık liseye yöneltmiştir (Akçasoy, 2019). Bu durum meslek lisesinde okumak istemeyen öğrencilerin de meslek liselerine girmesine neden olmuştur. Meslek lisesine gitmek istemeyen öğrencinin açık liseye gitmesi gerekmektedir. Bu durum sosyo-ekonomik durumu iyi olmadığ 1 için özel okula gidemeyen öğrenciler açısından meslek liselerini zorunluluk haline getirmiştir (Kablay, 2019). Meslek edinmek için bu liseleri tercih edenlerle, zorunlu olarak bu liseleri tercih edenler aynı eğitimi almakta bu durum kaynakların etkisiz kullanılması anlamına gelmektedir. Çünkü öğrencilerin uygulama eğitimlerinin okullarda yapılabilmesi, okullarda pek çok yatırımı gerekli kılmaktadır. Mezun olduktan sonra mesleğini yapmayacak kişilere bu eğitimi zorunlu tutmak ekonomik değildir.

MEB' in (2020: 25-26) verilerine göre ülkede 55 alanda 203 dalda mesleki eğitim verilmekte olup mesleki teknik eğitimin ortaöğretimdeki pay1 \%34'tür. 3591 adet Mesleki ve Teknik Ortaöğretim Kurumu bulunmakta olup bunun \%9,02'si (324) Mesleki Eğitim Merkezi (çıraklık), \%21,75'i (781) Çok Programlı Anadolu Lisesi iken \%69,23'ü (2486) Mesleki ve Teknik Anadolu Lisesidir. 2486 Mesleki ve Teknik Anadolu Lisesinin ise 631'i Özel Meslek Lisesi, 33'ü ise Organize Sanayi Bölgelerinde (OSB) açılan meslek liseleridir. Meslek liseleri artık sermeyenin de dikkatini çekmektedir. Mesleki ve teknik ortaöğretim kurumlarında eğitime devam eden öğrenci sayısı 1.421.704 olup, 127.963 öğrenci mesleki eğitim merkezlerinde, 1.293 .741 öğrenci ise Mesleki ve Teknik Anadolu Liselerinde eğitim almaktadır. Öğrencilerin \%60,94'ü erkek, \%39,06’s1 ise kız öğrencidir.

MEB'e (2018) göre mesleki ve teknik eğitimin amacı "sosyal ve ekonomik sektörler ile işbirliği içinde ulusal ve uluslararası mesleki yeterliliğe, meslek ahlakina ve mesleki değerlere sahip, yenilikçi, girişimci, üretken, ekonomiye değer katan ehil iş gücü yetiştirmek"tir. Bu amaçlara ulaşmak için mesleki ve teknik eğitimin öncelikleri aşağıdaki şekilde sıralanmaktadır:

- Gereksinimlere göre nitelikli işgücü yetiştirmek,

- Katılımcı (özellikle paydaşların katılımı) bir anlayışla bu eğitimi yönetmek,

\footnotetext{
${ }^{7} \mathrm{Bu}$ çalışmada mesleki ve teknik liseler için meslek lisesi kavramı tercih edilmiştir.
} 
- $\quad$ Mezun duruma gelenleri üretime katılacak şekilde yetiştirmek,

- Verilen eğitimi sürekli geliştirmek ve kalitesini yükseltmek,

- $\quad$ Piyasanın gereksinimlerine göre modüler öğretim programları hazırlamak,

- Verimlilik ve rekabet edebilirliği arttırmak için eğitimin sosyal ve sektörel olarak entegre edilmesi,

- Bireylere mesleğe ilişkin bilgi, beceri sağlamanın yanında değişime uyum sağlayabilmesi için yetkinlikler kazandırmak,

- $\quad$ Bilgi ve iletişim teknolojileri konusunda üst düzey beceri kazandırmak,

- Ahilik anlayışına uygun iş ahlakı edindirmek,

- İnsan odaklı kalkınmada etkili olmak,

- Dijital dönüşüme uygun yeni iş alanlarının oluşturularak istihdamı arttırmak için girişimcilik anlayışı kazandırmaktır.

Meslek liselerinin en önemli özelliklerinden birisi de bazı liselerin kendi döner sermayesini üretme kapasitesine sahip olmasıdır. MEB 2017-2018 verilerine göre Mesleki ve Teknik Anadolu Liselerinin \%25,24'ü döner sermaye geliri elde etmektedir. En fazla döner sermaye sırasıyla Ankara, İstanbul ve Antalya' daki okullarda yaratılmıştır. En yüksek gelir elde eden okullar ise Batman, Ankara ve Samsun'dadır. 2017 verilerine göre döner sermaye geliri olan 50 okulun toplam döner sermaye geliri 104.238.266'dır. Geliri en yüksek olan alanlar Konaklama ve Seyahat Hizmetleri Alanı (gelir 48.083.913TL), Mobilya ve İç Mekân Tasarımı Alanı (gelir 48.082.494 TL), Yiyecek İçecek Hizmetleri Alanı (gelir 47.870.085 TL) olup en fazla döner sermaye üreten okullar Turizm ve Otelcilik Meslek Liseleridir. (MEB, 2018: 40). Okulların üretim sürecinde hem öğrenciler hem de öğretmenler yer almaktadır.

Mesleki ve teknik eğitimde öğrencilerin okul tercihlerinde toplumsal cinsiyete göre bir dağılım görülmektedir. Erkek öğrencilerin \%90'1 "Metal Teknolojisi, Metalürji, Tesisat Teknolojisi ve İklimlendirme, Motorlu Araçlar Teknolojisi, Elektrik-Elektronik Teknolojisi, Uçak Bakım, Mobilya ve İç Mekan Tasarımı, Gemi Yapımı, Makine Teknolojisi, Endüstriyel Otomasyon Teknolojileri, Raylı Sistemler Teknolojisi, Denizcilik ve Tarım" alanlarında mesleki eğitim almayı tercih ederken; kız öğrencilerin \%90'1 "Çocuk Gelişimi ve Eğitimi, El Sanatları Teknolojisi, Aile ve Tüketici Hizmetleri, Hasta ve Yaşlı Hizmetleri, Güzellik ve Saç Bakım Hizmetleri, Giyim Üretim Teknolojisi ve Grafik ve Fotoğraf" alanlarında eğitim almıştır (MEB, 2018).

\section{Stajyerlerin Emek Piyasasındaki Durumuna İlişkin Bir Araştırma}

Meslek lisesinde okuyup bir meslek edinmek amacıyla teorik eğitim alan öğrencilerin beceri eğitimleri, eğitim aldıkları alana göre kamu kurum ve kuruluşlarında ya da özel işletmelerde yapilmaktadir.

\subsection{Araştırmanın Amacı}

$\mathrm{Bu}$ çalışma meslek liselerinde eğitim gören ve gerek eğitim döneminde gerekse yaz tatillerinde staj faaliyetinde bulunarak emek piyasasında yer alan stajyerlerin çalışma koşullarını ve staj süreçlerini incelemeyi amaçlamaktadır. Araştırmada stajyerlerin staj süreçleri, staj yapılacak kuruluşun belirlenmesi, çalışma koşulları, iş güvenliği, stajyerlerin kontrolü, ücret sistemi, işyerlerinde düzenlemelere uygun olarak çalıştırılıp çalıştırılmadığı, staj sürecinde yaşadıkları sorunları tespit etmek temel amaçtır. İkincil amaç da meslek liselerinde okuyan öğrencilerin bu liseleri seçme nedenleri ve mezuniyet sonrası istihdama katılma düşünceleri ve durumlarını incelemektir. 


\subsection{Araştırmanin yöntemi}

Çalışmada stajyerlerin emek piyasasındaki durumlarını anlamak için nitel araştırma yöntemi ile bir alan araştırması yapılmıştır. Sandelowski'ye göre (1996’dan aktaran Gönç Savran, 2012) nitel araştırmalar insanların dünyayı nasıl anladığını, yorumladığını, deneyimlediğini ve ürettiğini anlamayı amaçlamakta olup toplumsal olgulara ilişkin daha derin bilgi edinmeyi amaçlayan "neden, nasıl, ne kadar" gibi sorulara yanıt arayan araştırmalardır. Bu çalışmada özellikle meslek lisesi öğrencilerinin staj süreçlerini nasıl algıladıklarını, bu süreçte yaşadıkları sorunları, liseleri gerçekten meslek edinmek amacıyla mı tercih ettiklerini öğrenmek amaçlandığından nitel araştırma yöntemi tercih edilmiştir.

Alandaki sorunları daha iyi kavrayabilmek amacıyla yarı yapılandırılmış görüşme formu kullanılmıştır. Araştırmanın evrenini Endüstri Meslek Lisesi (EML), Turizm ve Otelcilik Meslek Lisesi (TOML) ve Sağlık Meslek Lisesi (SML) öğrencileri oluşturmaktadır. Kota örneklem seçim tekniği tercih edilmiştir. İlk kota meslek lisesi türlerine göre oluşturulmuştur. Meslek lisesi türlerinin çok fazla olması nedeniyle mal ve hizmet üretim süreçlerinde daha yoğun bir staj dönemi geçiren Endüstri Meslek Lisesinde özellikle Mobilya ve İç Mekân Tasarımı Bölümleri ile Turizm ve Otelcilik Meslek Lisesi öğrencileri ve öğretmenleri görüşme kapsamına alınmıştır Ayrıca uzun bir geçmişe sahip olan ve hemşire yetiştiren programlarda son yıllarda yapılan isim değişikliği ile artık hemşire değil, hemşire yardımcısı yetiştirilmesi nedeniyle bunun eğitim sürecine, istihdama katılıma etkilerini incelemek amacıyla Sağlık Meslek Liseleri de kapsama dahil edilmiştir. Emek süreçlerini ve sorunları daha iyi kavrayabilmek amacıyla görüşmeler stajyerlik süresini bitiren meslek lisesi mezunları ile yapılmıştır. Bu tercihin üç nedeni bulunmaktadır. İlki okul ile bağlantının kalmaması nedeniyle not, mezuniyet gibi konularda tedirginlik duyulmasını engellemek, ikincisi; görüşme yapılan kişilerin staj sürecini ve istihdam olanaklarını daha iyi değerlendirmesi için bu süreci bitirmiş olmasının gerekmesi, üçüncüsü ise 18 yaşını bitirmiş kişilerle görüşme yapma isteğidir. Çalışmada öğrencilerin yanı sıra öğretmenlerle de görüşmeler yapılmıştır. Bunun nedeni ise öğretmenlerin yasal prosedürleri bilmesi, öğrencilerin staj süreçlerini takip etmesi, alanda olan değişikliklere ve sorunlara hâkim olmasıdır.

Görüşmeciler seçilirken ikinci kota tercih edilmiştir. Büyük ve küçük merkezlerde özellikle staj yerinin belirlenmesinde, staj süreçlerinde sorunların farklılaşabileceği düşünülerek hem ilçe hem de il merkezlerindeki meslek lisesi mezunları ve öğretmenlerle görüşmeler gerçekleştirilmiştir. Görüşme yapılan kişiler Ankara, İzmir, İstanbul, Ordu, Samsun ve Trabzon il ve ilçelerinde yaşamaktadırlar. Ancak öğretmen ve bazı mezunların yaşadıkları şehrin belirtilmemesi isteği nedeniyle Tablo 2'de görüşmecilerin yaşadıkları il belirtilmemiştir. Yarı yapılandırılmış soru formundaki sorular araştırmacı tarafından oluşturulmuştur. Soru formunda meslek lisesini tercih nedenleri, staj sürecine ilişkin bilgiler, yaşanan sorunlar, mezunların aldıkları eğitime uygun şekilde istihdama yönelme durumlarına ilişkin sorular bulunmaktadır. Çalışmanın örneklemini; 12 meslek lisesi mezunu ve 8 meslek lisesi öğretmeni olmak üzere toplam 20 kişi oluşturmaktadır. Çalışmaya katılan öğretmenlerin bazılarının meslek lisesi mezunu olması eski staj uygulamaları ile yeni uygulamaları karşılaştırma açısından yarar sağlamıştır. Görüşmeler 2019 yılı Mart- Aralık aylarında gerçekleştirilmiştir.

Alan araştırması 2020 yılı öncesi gerçekleştirildiği, niteliksel bir çalışma olduğu, az sayıda kişi ile görüşüldüğü, görüşmecilerin hepsinin 18 yaşından büyük bireyler olduğu ve gönüllülük çerçevesinde yapıldığı için etik kurul belgesi alınmamış ancak çalışmada etik kurallara uyulmuştur. 
Mezun durumdaki kişilerle görüşülmüş olup bu kişilerle okul dış1 mekanlarda görüşmelerde bulunulduğu için okuldan izin almaya gerek bulunmamaktadır. Öğretmenlerin de görüşmeleri okul dışı mekanlarda yapılmış olup sadece Turizm ve Otelcilik Meslek Lisesinden iki öğretmenle okul müdürünün izni ile okulda görüşme gerçekleştirilmiş, atölyeler gezilmiştir. Görüşmecilerden isim soyisim gibi kişisel bilgiler istenmemiş, istedikleri zaman görüşmeden ayırabilecekleri belirtilmiş, görüşmeyi kabul edenlerle görüşmeler gerçekleştirilmiştir. Görüşmeler esnasında herhangi bir sorun yaşayan veya görüşmeyi terk etmek isteyen kimse olmamıştır. Görüşmelerde ses kayıt cihazı tercih edilmiştir. Ancak ses kaydı alınmasını istemeyenlerle görüşmeler not tutarak yapılmıştır.

Tablo 2: Görüşmecilerin Sosyo-demografik Özellikleri

\begin{tabular}{|c|c|c|c|c|c|}
\hline $\begin{array}{l}\text { Görüşmeci No- } \\
\text { İ́sim }^{8} \text { ve Grubu }\end{array}$ & Meslek Lisesi Türü & $\begin{array}{l}\text { Cinsi- } \\
\text { yet }\end{array}$ & Yaş & Hizmet Yılı & Ĕgitim \\
\hline $\begin{array}{l}\text { 1-Seher } \\
\text { ML Mezunu }\end{array}$ & $\begin{array}{l}\text { Sağlık Meslek Lisesi } \\
\text { Radyoloji }\end{array}$ & Kadın & 24 & - & Lise \\
\hline $\begin{array}{l}\text { 2- Yağmur } \\
\text { ML Mezunu }\end{array}$ & $\begin{array}{l}\text { Sağlık Meslek Lisesi } \\
\text { Hemşirelik }\end{array}$ & Kadın & 22 & 2 & Lise \\
\hline $\begin{array}{l}\text { 3- Güneş } \\
\text { ML Mezunu }\end{array}$ & $\begin{array}{l}\text { Sağlık Meslek Lisesi } \\
\text { Hemşirelik }\end{array}$ & Kadın & 22 & - & Lise \\
\hline $\begin{array}{l}\text { 4- Sila } \\
\text { ML Mezunu }\end{array}$ & $\begin{array}{l}\text { Sağlık Meslek Lisesi } \\
\text { Hemşirelik }\end{array}$ & Kadın & 26 & 5 & Üniversite \\
\hline $\begin{array}{l}\text { 5- Fatma } \\
\text { ML Mezunu }\end{array}$ & Ticaret Lisesi & Kadın & 21 & - & Lise \\
\hline $\begin{array}{l}\text { 6- Rüzgar } \\
\text { ML Mezunu }\end{array}$ & $\begin{array}{l}\text { Endüstri Meslek } \\
\text { Lisesi }\end{array}$ & Erkek & 21 & 4 & Lise \\
\hline $\begin{array}{l}\text { 7- Doruk } \\
\text { ML Mezunu }\end{array}$ & $\begin{array}{l}\text { Endüstri Meslek } \\
\text { Lisesi }\end{array}$ & Erkek & 22 & - & Üniversite \\
\hline $\begin{array}{l}\text { 8- Ahmet } \\
\text { ML Mezunu }\end{array}$ & $\begin{array}{l}\text { Endüstri Meslek } \\
\text { Lisesi }\end{array}$ & Erkek & 21 & - & Lise \\
\hline $\begin{array}{l}\text { 9- Menekşe } \\
\text { ML Mezunu }\end{array}$ & $\begin{array}{l}\text { Turizm ve Otelcilik } \\
\text { Meslek Lisesi }\end{array}$ & Kadın & 20 & 2 & Lise \\
\hline $\begin{array}{l}\text { 10- Ali } \\
\text { ML Mezunu }\end{array}$ & $\begin{array}{l}\text { Turizm ve Otelcilik } \\
\text { Meslek Lisesi }\end{array}$ & Erkek & 22 & 4 & Lise \\
\hline $\begin{array}{l}\text { 11- Mehmet } \\
\text { ML Mezunu }\end{array}$ & $\begin{array}{l}\text { Turizm ve Otelcilik } \\
\text { Meslek Lisesi }\end{array}$ & Erkek & 21 & 3 & Lise \\
\hline $\begin{array}{l}\text { 12- Emre } \\
\text { ML Mezunu }\end{array}$ & $\begin{array}{l}\text { Turizm ve Otelcilik } \\
\text { Meslek Lisesi }\end{array}$ & Erkek & 21 & 3 & Lise \\
\hline $\begin{array}{l}\text { 13- Kadriye } \\
\text { Öğretmen }\end{array}$ & $\begin{array}{l}\text { Turizm ve Otelcilik } \\
\text { ML }\end{array}$ & Kadın & 44 & $\begin{array}{l}21 \text { yil } \\
2 \text { yildır bu okulda }\end{array}$ & $\begin{array}{l}\text { Üniversite } \\
\text { ML çıkışlı }\end{array}$ \\
\hline $\begin{array}{l}\text { 14- Ayşe } \\
\text { Öğretmen }\end{array}$ & $\begin{array}{l}\text { Turizm ve Otelcilik } \\
\text { ML }\end{array}$ & Kadın & 441 & $\begin{array}{l}21 \text { yıl } \\
7 \text { yıldır bu okulda }\end{array}$ & $\begin{array}{l}\text { Üniversite } \\
\text { ML çıkışlı }\end{array}$ \\
\hline $\begin{array}{l}\text { 15- Toprak } \\
\text { Öğretmen }\end{array}$ & $\begin{array}{l}\text { Turizm ve Otelcilik } \\
\text { ML }\end{array}$ & Erkek & 444 & $\begin{array}{l}21 \text { yıl } \\
10 \text { yildır bu okulda }\end{array}$ & $\begin{array}{l}\text { Üniversite } \\
\text { ML çıkışlı }\end{array}$ \\
\hline
\end{tabular}

${ }^{8}$ Görüşmecilerin kimlik bilgilerinin gizli tutulması nedeniyle farklı isimler kullanılmıştır. 
Kablay, S. (2021), "Stajyer Öğrencilerin Emek Süreçleri: Meslek Liseleri Üzerine Niteliksel Bir Araştırma”, Politik Ekonomik Kuram, 5 (1), 132-160.

\begin{tabular}{|l|l|l|l|l|l|}
\hline $\begin{array}{l}\text { 16- Bulut } \\
\text { Öğretmen }\end{array}$ & $\begin{array}{l}\text { Turizm ve Otelcilik } \\
\text { ML }\end{array}$ & Erkek & $\mathbf{4 6}$ & $\begin{array}{l}\mathbf{2 4} \text { yıl } \\
\mathbf{1 5} \text { yıldır bu okulda }\end{array}$ & $\begin{array}{l}\text { Üniversite } \\
\text { ML çısışlı }\end{array}$ \\
\hline $\begin{array}{l}\text { 17- Başak } \\
\text { Öğretmen }\end{array}$ & $\begin{array}{l}\text { Sağık Meslek Lisesi } \\
\text { Yardımcı Hemşirelik }\end{array}$ & Kadın & $\mathbf{3 6}$ & $\begin{array}{l}\mathbf{9} \text { yıl } \\
\mathbf{3} \text { yıldır bu okulda }\end{array}$ & Üniversite \\
\hline $\begin{array}{l}\text { 18- Bahar } \\
\text { Öğretmen }\end{array}$ & $\begin{array}{l}\text { Sağlık Meslek Lisesi } \\
\text { Yardımcı Hemşirelik }\end{array}$ & Kadın & $\mathbf{4 6}$ & $\begin{array}{l}\mathbf{2 4} \text { yıldır } \\
\mathbf{5} \text { yıldır bu okulda }\end{array}$ & $\begin{array}{l}\text { Üniversite } \\
\text { ML çıış̧ı }\end{array}$ \\
\hline $\begin{array}{l}\text { 19- Bora } \\
\text { Öğretmen }\end{array}$ & $\begin{array}{l}\text { Endüstri Meslek } \\
\text { Lisesi (Mobilya...) }\end{array}$ & Erkek & $\mathbf{4 9}$ & $\begin{array}{l}\mathbf{2 8} \text { yıl } \\
\mathbf{9} \text { yıldır bu okulda }\end{array}$ & $\begin{array}{l}\text { Üniversite } \\
\text { ML çıkş̧lı }\end{array}$ \\
\hline $\begin{array}{l}\text { 20- Mert } \\
\text { Öğretmen }\end{array}$ & $\begin{array}{l}\text { Endüstri Meslek } \\
\text { Lisesi (Mobilya...) }\end{array}$ & Erkek & $\mathbf{4 2}$ & $\begin{array}{l}\mathbf{2 0} \text { yıl } \\
\mathbf{3} \text { yıldır bu okulda }\end{array}$ & Üniversite \\
\hline
\end{tabular}

Derinlemesine görüşmelerin yapıldığ 12 meslek lisesi mezunu ve 8 meslek lisesi öğretmeninin sosyo-demografik özelliklerine ilişkin bilgiler Tablo 2'de görülmektedir. Görüşmeye katılan mezunların tamamının yaşları 20-26 yaş arasında olup, mezunlardan 6'sı kadın, 6'sı da erkektir. Mezunlardan 4'ü Sağlık Meslek Lisesi, 1’i Ticaret Lisesi, 3’ü Endüstri Meslek Lisesi, 4'ü de Turizm ve Otelcilik Meslek Lisesi mezunudur. Mezunlardan 7'si okudukları bölümle alakalı bir işte çalışmış, içlerinden birisi mesleği bırakmıştır. 5 mezun alanla ilgili hiçbir işte çalışmamıştır. Mezunlardan 2'si üniversiteyi bitirmiş olup, 4'ü halen üniversite öğrenimine devam etmektedir. Görüşme yapılan öğretmenlerden 4'ü Turizm ve Otelcilik Meslek Lisesi, 2'si Sağlık Meslek Lisesi, 2'si de Endüstri Meslek Lisesi öğretmenidir. Öğretmenlerin 6's1 meslek lisesi kökenlidir. Öğretmenlerin tamamı 36-49 yaş aralığında olup, meslekteki hizmet yılları da 9 ile 28 yıl arasındadır. Öğretmenler meslek liselerindeki işleyişi, eski ve yeni uygulamaları bilecek kadar uzun bir süredir bu mesleği yapmaktadırlar.

\subsection{Bölüm seçme nedenleri ve gelecek beklentisi}

Meslek liselerinin kuruluş amacı ortaöğretimdeki öğrencilere bir mesleğin gerektirdiği bilgi ve becerileri kazandırmaktadır. Dolayısıyla öğrencilerin kaydoldukları alandaki mesleği öğrenmek amaciyla bu liseleri tercih etmiş olması gerekmektedir. Öğrenci ve öğretmenlerle yapılan görüşmelerde meslek liselerinin türüne, öğrencilerin sosyoekonomik durumuna göre bölüm seçme nedenlerinin farklılaştığı tespit edilmiştir. Öğrencilerin liselere geçiş sınavında düşük puan alması nedeniyle mecburen bu liselere kayıt yaptırdığı tespit edilmiştir. Bölümü isteyerek tercih edenlerin oranının az olduğu öğretmenlerle yapılan görüşmelerde de dile getirilmiştir. Bu durum öğrencilerin mezuniyet sonrası istihdam alanı olarak eğitim aldıkları alanı seçmemesine neden olmaktadır. Görüşme yapılan bir teknik lise, bir de endüstri meslek lisesi mezunu puan nedeniyle bölümü seçtiğini, eğer zorunlu olmasaydı düz lisede okumak istediğini belirtmiştir. Okulunu isteyerek seçtiğini söyleyen bir mezun (Rüzgar, yaş 21) mobilya ve ahşap işlerini sevdiğini, bölümü bu nedenle seçtiğini belirtmiştir.

Sağlık Meslek Liseleri içinse hem isteyerek bu liseyi seçme hem de ailenin iş bulma kolaylığ nedeniyle bu liseyi istemesi öne çıkmaktadır. Ancak görüşme yapılan mezunlardan üçü de hemşire unvanına sahip olup Sağlık Meslek Liselerindeki hemşire yardımcıllğı unvanı veren bölümleri okumamışlardır. Buna rağmen görüş̧e yapılan Sağlık Meslek Lisesi öğrencilerinden sadece birisi şu anda mesleğini yapmakta olup ayrıca üniversitede de aynı bölümde eğitim almıştır. Bu kişi:

"Küçüklügümden beri hep hemşire olmak istiyordum. Bu yüzden Sağllk Meslek Lisesine gittim. Oradan mezun olunca üniversitede de aynı bölümü tercih ettim. Beş ylldır da bu 
mesleği yapıyorum. Mesleğimi seviyorum. Bu bölümü severek tercih ettim. Evet, işte yaşadığımı birçok sorun var ama bu işi bırakmayı hiç düşünmedim” şeklinde düşüncelerini belirtmiştir (Sıla, yaş 26).

Bölümü isteyerek tercih ettiğini söyleyen, mezuniyet sonrası iki yıl da çalışan görüşmeci ise:

"Ben mesleği çok istiyordum. Ben yatılı da olsa okuyacă̆ım dedim. Çok da mutlu oldum. Sonrasında bu işi de yaptım. Ama daha güncel bir bölümde okumak istedim, başka bir bölümü tercih ettim. Özelde çalışırken mesleğin çok vicdanlı yapılmadığını düşünerek mesleği bıraktım. Bir daha da yapamam” (Yağmur, yaş 22) diyerek alanda çalışmak istemediğini ifade etmiştir.

Diğer mezunların ise durumu biraz farklıdır. Mezunlardan biri radyoloji birisi de hemşirelik bölümü mezunudur. Bölümü tercih nedeni iş bulma kolaylığı olduğunu söyleyen görüşmeci:

"Yaş büyüyünce, diğer bölümlerin puanı yüksek olunca sağlık alanına yöneldim. Şehir dışı bir yere de gitmek istemedim. İs olanağ olabilir diye de tercih ettim. Ama devlet kadro açmadı. Şu anda başka alanda üniversite eğitimi alıyorum. İlk zamanlar alan değiştirdiğim için çok üzüldüm. $O$ alanda yüksek lisans da yapmak isterdim ama o alanla uyuşturabileceğim bir sosyal bilim alanında okuyorum şu anda. 'Olanak çıksa şu anda sağlık alanında çalışmak ister miydin?' Özel sektörde istemezdim. Çünkü suistimallere açık bir bölüm bizim bölümümüz. Ve de riskli. Oradaki çalı̧̧anlara izinleri tam verilmiyor, çalışma saatleri çok değişken. Tabiri caizse özel sektör sizin etinizden, sütünüzden yararlanıyor" (Seher, yaş 24).

"Ailem tarafindan yönlendirildim. Aslında Fen Lisesi ya da Anadolu Lisesi istiyordum. Bırakmak için okulda özellikle başarısız oldum. Derslerim zayıf geldi ama almadılar okuldan. Hemşirelik aslında isteyerek yapılması gereken bir meslek. Ben hiç istemedim. $O$ yüzden mezun olunca çalışmak da istemedim. Üniversite sınavına girip başka bölümde okumaya başladım. Illeriki dönemde de hemşirelik yapmayı düşünmüyorum” (Güneş, yaş 22) şeklinde konuşan mezun aslında bu tür liselerde öğrenci istemeden eğitim aldığında gelecek dönemde bu mesleği yapmayacağına iyi bir örnek oluşturmaktadır.

Teknik liselerde de istemeden bölümü tercih etme durumu yaygındır. Özellikle son yıllarda normal liselerin sayısının azaltılması öğrenciler için meslek liselerini bir zorunluluk haline getirmiştir. Teknik ve Endüstri Meslek Lisesi Mezunu öğrencilerle yapılan görüşmelerde öğrencilerden sadece birisinin bölümü isteyerek tercih ettiği ve şu anda da alanda çalıştı̆̆ı öğrenilmiştir. "Bölümü ben istedim. Ahşap işlerine merakım vardı. Diğer Matematik gibi dersler ilgimi çekmiyordu. Liseden mezun olup çalışmak istiyordum. Mobilya bölümünü tercih ettim. Şimdi de Siteler'de 9 çalışıyorum. Biraz yorucu ama işimi seviyorum” (Rüzgar, yaş 21). Görüşmecilerden biri bölümü istemeden seçtiğini sonra başka bir alanda Meslek Yüksek Okulunu bitirdiğini ifade etmiştir (Doruk, yaş 22).

Turizm ve Otelcilik Meslek Liselerinde ise durum daha olumludur. Bölümü tercih eden öğrenciler bilinçli olarak tercih etmekte, hatta kendi akrabalarının çocuklarını da bu liseye kayıt yaptırma yönünde motive etmektedirler. Turizm ve Otelcilik Meslek Lisesi öğretmenleri ile yapılan görüşmelerde öğrencilerin arasında çok sayıda akraba olduğu, sosyoekonomik durumu kötü olan

\footnotetext{
${ }^{9}$ Ankara'da mobilya üretiminin yaygın yapıldı̆̆
} 
bireyler için erken yaşta hem ekonomik gelir elde etmenin hem de iş bulma kolaylığının bu okulları tercihi arttırdığ 1 ifade edilmiştir. Ancak az da olsa bu liselerde de isteyerek tercih yapmayan öğrenciler vardır ve bunlar özellikle istihdamın mevsimlik olması dolayısıyla belli bir süre sonra alan değiştirme isteğinde olmaktadırlar. Görüşme gerçekleştirilen dört mezun da bölümü isteyerek seçtiğini alanda çalıştıklarını ifade etmişlerdir. Ancak görüşmecilerden kadın olan "Bölümü iş bulma kolaylı̆̆ı nedeniyle seçtim. Ama çalışma şartları çok ağır. Evlenince ya da çocuk sahibi olunca bu işi yapmak istemiyorum" Menekşe, yaş 20) şeklinde düşüncelerini dile getirerek geçici bir dönem için mesleğini yapacağını ifade etmiştir.

Öğretmenler Turizm ve Otelcilik Liselerini genellikle öğrencilerin isteyerek tercih ettiğini belirtmiştir. Öğrenciler "meslek lisesini neden tercih ediyorlar, puanı yetmediği için mi yoksa istedikleri için mi” sorusuna Turizm ve Otelcilik Lisesi öğretmenlerinin verdiği yanıtlar şu şekildedir: "Puanı yetmediği için diyemeyiz çünkü şehrin dışında bir okul, geliş gidişi zor, servis ücreti gerektiriyor. Dolayısıyla çocuk burayı tanıyarak geliyor. Öğrencilere neden tercih ettiğini sorduğumuzda 'duydum burayı ondan geliyorum, iş bulma olanağının, geleceğinin olduğunu' söylüyorlar. Yani iş bulmaları kolay olduğu için tercih ediyorlar" (Kadriye, yaş 44), "İş bulma kolaylı̆̆ının yanı sıra tanıdık vasıtasıyla gelenler de oluyor. Bir bakıyorsunuz öğrencilerin soyadları tutuyor. Kardeşlerden gelenler, kuzenlerden gelenler çok oluyor” (Toprak, yaş 44).

Sağlık Meslek Liselerinde programın adının değişmesi bu liselerin geçmişte olduğu gibi isteyerek tercih edilmesinin önüne geçmektedir. Bu lisedeki öğretmenlerin ikisi de öğrencilerin genellikle okulu isteyerek seçmediğini, puan nedeniyle okula yerleştiğini belirtmiştir. Bu okuldaki öğretmenlerden biri:

"Genelde aileleri tercih ediyor. Anadolu Liselerinin sayısı azaltıldı̆̆ için Sağlık Meslek Lisesini mecburen tercih eden ögrrenciler de var. Mesela diyor ki 'ben Anadolu Lisesine gitmek istiyordum, puanım yetmedi. Puanım burayı tuttu. O yüzden geldim. Ístiyor muyum? Hayır istemiyorum.' O yüzden biz de derslerde bu ögrencileri adapte etmek için çok zorlanıyoruz. Bitirdikten sonra zaten sağlık alanında çalışmak istemiyorsa gerçekten de adaptasyon konusunda sıkıntı çekiyor” şeklinde durumu özetlemiştir (Başak, yaş 36).

Teknik veya Endüstri Meslek Liselerinde ise bölüm tercihlerinde çok az öğrencinin isteyerek bölümü tercih ettiği, bazı alanları tercihin fazla olduğu, ama genelde diğer liselere yerleşemediği için öğrencilerin bu okulları tercih ettiği öğretmenler ve öğrenciler tarafından ifade edilmiştir. Bir öğretmen "Buraya gelen öğrencilerin çoğu diğer okullara yerleşemediği için zorunlu tercih yapıyor. Aslında meslek ögrenilen okulların gönüllü tercih edilmesi gerek. Çünkü bu okullar aslında maliyet açısından pahalı okullar. Atölyelerin kurulması, makineler alınması gerekiyor. Bu işi yapmayacak kişilere bu işi ögretmeye ve sevdirmeye çalışıyoruz" ifadesi ile istenmeden bölümün seçilmesinin yarattığı sorunları ifade etmiştir (Bora, yaş 49).

\section{4.Ë̆itim süreci ve staja ilişkin durum}

Mesleki lisesi öğrencileri teorik eğitimleri okul ve kurumlarında, işletmelerde; beceri eğitimlerini ise işletmelerde almaktadırlar. Anadolu Meslek Programı öğrencileri 12. sınıfta üç gün beceri eğitimi almaktadır. Staj ise MEB (2018) tarafından Anadolu teknik programındaki öğrencilerin "ilgi, beceri, tutum ve davranışlarını geliştirmelerini, iş hayatına uyumlarını, gerçek üretim ve hizmet ortamında yetişmelerini ve okulda olmayan tesis, araç-gereci tanımalarını sağlamak amacılla 40 iş günü işletmelerde uygulama eğitimi gördüğ̈ mesleki ĕgitim" olarak 
tanımlanmaktadır. Öğrenciler ayrıca kardeş okul, uluslararası ikili anlaşma ve protokoller ile projeler kapsamında yurtdışında da bu olanaklardan faydalanabilmektedir.

Okuldaki eğitim modüllerinin kimler tarafından hazırlandığı ve güncellendiğine ilişki öğretmenler genellikle MEB'in modülleri güncellediğini belirtmiş en ayrıntılı bilgi Turizm ve Otelcilik Meslek Lisesi öğretmeninden gelmiştir "Ben geçen yıl modüllerin güncellenmesi, yapılandırllmasıyla ilgili kursa gittim İstanbul'da. Kursta modüllerdeki eksiklikleri, alandan çıkartılmasını istediğimiz şeyleri çıkartıp modülleri güncelledik. Biz de sürece katıllyoruz". (Ayşe, yaş 41).

Öğrencilere ve öğretmenlere staj sürecine ilişkin staj yerinin kim tarafından ayarlandığı, staja kaçıncı sınıfta ne kadar süre ile çıkıldığı, teorik ve uygulama eğitimlerinin içeriği, staj notlarının nasıl verildiği, stajda ne tür işler yapıldığına ilişkin sorular yöneltilmiştir.

Turizm Otelcilik Meslek Lisesi öğretmenleri eğitim sürecine ilişkin şu bilgileri vermiştir:

"Yiyecek içecek bölümüne yeni gelmiş ögrencilerimize öncelikle beslenme dersi, arkasindan da yiyeceklerin özellikleri, yiyeceklerin içerisinde olan maddelerin özellikleri, vücut için yararlarl, dolayısılyla da yaş grupları ve özel durumlara göre örneğin hamilelik, diyabet hastaliklarında kişilerin yemesi gereken yiyeceklerin türleri ve buna göre menü planlamaya kadar eğitim veriyoruz. Bu süreçte kullanacakları araç gereçler, bunların özellikleri, kullanışşekillerine kadar tüm aşamaları uygulamaya geçmeden önce teorik aşamada biz veriyoruz... Pratik eğitimde çocuk tamamen sahada bu işi yapacak şekilde uygulama ögreniyor. Burada öğrenci ön planda. Öğrenci herhangi bir konuyu ürün olarak ortaya nasıl çılkarabileceğine baklyor... ürünü hazırllyor, sunum olarak da ilk bize gösteriyor" (Kadriye, yaş 44). Diğer öğretmen de "Uygulamalar; Türk mutfă̆l, dünya mutfağl, kokteyl uygulamalarl alkolsüz, dersin içeriğinde ne varsa onu öğretiyoruz. Peçete katlamadan, yemek hazırlamaya kadar" (Ayşe, yaş 41) şeklinde işin her aşamasını öğrettiklerini ifade etmiştir.

"Sektörde ortaya çıkarılacak ürün hayatta yer alıyor mu, mutfăga girebilecek ürün mü, buna önem veriliyor eğitimde. Zaman zaman yöresel ürünler konusunda da önem veriliyor. Gittiğimiz yerdeki mutfaklarda da incelemeler yaplyoruz. Teorik ĕgitimlerimiz de aslında hep pratiğe dönük oluyor. Gezi inceleme sonuçlarından çok yararlaniyoruz eğitimlerde" (Toprak, yaş 44).

Turizm ve Otelcilik Bölümü öğrencileri okuldaki eğitimlerde genelde uygulamaya dönük eğitimler verildiğini, sunumdan ürün hazırlamaya, ürünün özelliklerinden kullanılan malzemelere kadar ilk eğitimi okulda aldıklarını ve staja çıkarken temel bilgilerle donandıklarını ifade etmişlerdir.

Sağlık Meslek Lisesi öğretmeni ise eğitimin içeriğine ilişkin "Pratikte Meslek Esasları dersini daha öne çıkarıyoruz. Teoride de Anatomi, Enfeksiyon Hastalıklarl, Aseptik Uygulamalar üzerinde yoğun olarak duruyoruz" (Bahar, yaş 46) şeklinde bilgi vermiştir.

Endüstri Meslek Lisesi öğretmenleri ise hem genel kültür derslerinin hem de alana ilişkin derslerin müfredatta yer aldığını ama alan derslerinin ağırlığının ve kredilerinin daha fazla olduğunu söyleyerek, staj sürecindeki eğitime ilişkin bilgi vermişlerdir.

"10. sinıftan itibaren meslek dersleri ağırlıklıdır. 11. sinıfta da meslek dersleri ağırlıkta. 10 ve 11.sinıfta atölye çalışmaları var. 12. sinıf zaten çoğunlukla stajda geçiyor. 36 hafta, 
Kablay, S. (2021), "Stajyer Öğrencilerin Emek Süreçleri: Meslek Liseleri Üzerine Niteliksel Bir Araştırma”, Politik Ekonomik Kuram, 5 (1), 132-160.

haftada 3 gün, günlük en az 8 saattir staj süresi. Bazı işletmeler öğrenciyi Cumartesi de çalıştırmak istiyor. O bizim dışımızda. Kendi aralarında anlaşıyorlar. Öğrencilere bunun için farkll bir ücret veriliyor. Dersler var ama çok az son sinıfta. 3 gün staj 2 gün teorik ders görüyorlar. Bu 2 günde genel kültür de var meslek dersi de var. Bu meslek dersleri bizim bölümde genelde çizim üzerine. Bilgisayar veya manuel proje çizme ile ilgili. Bizim bölümlerde yaz stajı yok. Stajda branşları ile ilgili işletmelere gidiyorlar. Atölyelere gidenler de var, fabrikalara gidenler de. Bulunduklarl yerde işyeri bunlara ne kadar görev verirse onu yaplyorlar ama kapasitelerine göre görev veriyorlar...Kalfa statüsünde bir iş vermiyorlar...Öğrenciyi şu işi yapma, bu iş yap gibi bir yönlendirmemiz yok. En büyük yönlendirmemiz işyerinin kurallarına talimatlarına uyun. İsyerindekiler bu konuda zaten tecrübeliler...Staj yerinin belirlenmesinde biz öğrenciyi yönlendiriyoruz. Bulamazlarsa biz yardımcı oluyoruz. Daha önce ögrencilerimizin staj yaptığ işletmelerin adreslerini verip gidin görüşü̈n diyoruz, anlaşmayı kendilerine bıraklyoruz. Çoğunluğuna velilerinizle gidin görüşün diyoruz. Okul-öğrenci ve işyeri arasında bir sözleşme yapllyyor. Orada kimlik bilgileri, bir sürü hükümler var, işletmenin bilgileri var, vergi kimlik bilgileri, hesap numarası bilgileri var. Öğrencinin ve işletmenin sorumlulukları sözleşmede yer alıyor. Stajda kontrol için işletmelere gidiyoruz. Ortalama iki haftada bir kontrole gidiyoruz. İsletmelerde Beceri Ĕgitimi diye ders sayllyyor bu zaten. Belli bir saat yazllyyor ders programında. O süre içinde işyerlerine gidiyoruz...Stajda yaptıklarına iliş̧kin staj dosyası tutup, yaptıklart işin resmini çekiyorlar. Bir dönemde en az 8 tane işin teknik resmini çizmeleri gerekiyor. O resim üzerinden sorumlu usta öğretici ögrencilere not veriyor. Dönem bitince biz okulda bir sinav daha yaptyoruz beceri ile ilgili. O sinavin sonucu ile dosyadan gelen notun belli yüzdelerini alarak nota karar veriyoruz. Atölye uygulama notu belirlenmiş oluyor. Ustalar genelde yüksek not veriyorlar. Çok gerçekçi değil notlar. İsyerine gittiğimizde işverene de öğrenciye de sorular soruyoruz. İyi davranlyorlar mi, ne iş yaplyorsun, ücretin veriliyor mu diye. Olumsuzluk varsa çözmeye çalışlyoruz bir işyerinde sayı fazla olunca işe gitmeme gibi durumları olabiliyor. Ay sonunda işyerinden puantaj alıyoruz. Gelmediği gün devamsız yazıllyor. Devletin katklsı ona göre kesiliyor. Devlet kesiyor ama işyeri kesmiyor." (Bora, yaş 49).

Aslında öğrencilerin staj yerinin öğrenci tarafindan belirlenmesi öğrencilerin bazen staj yeri bulamamasına veya çok uğraşmasına (Kablay, 2021), bazen de bölümleriyle ilgisiz yerlerde staj yapmalarına neden olmaktadır (Düzgün ve Alikoç, 2020). Staj yerlerinin okullar tarafından ayarlanması çoğu zaman öğrencilerin güvensiz yerlerde staj yapmasını engellemekte onları korumaktadır (Kablay, 2021). İki Endüstri Meslek Lisesi ve bir Ticaret Lisesi öğrencisi staj yerlerini kendilerinin ayarladığını, süreçte biraz zorlandıklarını ifade etmişler, EML mezunları işyerlerinde aldıkları eğitime uygun işler yaptıklarını ifade ederken Ticaret Lisesi mezunu, staj sürecinin çok da verimli geçmediğini şu sözlerle ifa etmiştir: "İ̧syerini zor buldum. Staj yaparken de aslında bana ihtiyaçları olmadı̆̆ için sürekli ayak işi yaptım. Çay da demledim, başka yerlere evrak da getirip götürdüm. Doğru düzgün teknik resim filan çizmedim. Neticede zaten okulu da isteyerek seçmemiştim. Stajda da bu düşüncenin ne kadar doğru olduğunu anladım ve bu alanda çalışmamaya kesin olarak karar verdim" (Fatma, yaş 21).

Staj yerinin kim tarafından ayarlandığı, stajda ne tür işler yapıldığına ilişkin soruya Sağlık Meslek Lisesi Mezunu bir görüşmecinin yanıtı şu şekildedir: 
"Staj yerini okul ayarlıyordu. Yaz stajının yerini kişiler kendileri ayarlıyordu. Benim memleketim İmir olduğu için yaz stajımı orada yaptım. Stajda kendi bölümümle ilgili işleri yaptım. Hastanede bizi koruyorlardı zaten. Orada kan alma, damar yolu açma, makinelerin kalibrasyonu işlerini yapıyorduk. Başlangıçta pahalı cihazlar olduğu için bu işleri şeflerle yapıyorduk. Öğrenince kendimiz yapmaya başladık. Stajda çok tehlikeli bulaşa neden olabilecek işler vardı. İlaç ya da vücut sıvısı nedeniyle. Bunlarla ilgili çalışırken çok dikkat etmemiz gerekiyordu. Güçlü farmastotik ilaçları hazırlarken çok dikkatli olmamı gerekiyordu. Bunları uygularken ne gibi kişisel koruyucu donanımlar kullanıyordunuz'. Özel giysilerimiz, kurşun önlüklerimiz, kalın eldivenlerimiz vardl. Bizi koruyorlardl. Onların aldığ önlemleri biz de alıyorduk. Bizlere de dozimetre veriyorlard. Stajda kendi hastanemizde basit spanç yapma gibi işler yapmıyorduk ama başka bölümlere gidince bize bu tür işler yaptırllmaya çallşllıyordu. Getir götür pek fazla yapmadık. Okul özel okuldu ve ögrenciler de cevval olduğundan bize yaptıramadılar ama saf tipler yapmış olabilir. Öğrenci sayısını okul belirliyordu. Staja giderken yolu kendimiz karşıllyorduk. Öğrenci kimliklerimizle hastane yemekhanesinde yemek yiyebiliyorduk. Ödemiyorduk ücret" (Görüşmeci 1, SML Mezunu).

"Staj yerini okul ayarlıyordu. Staj dersine göre yeri belirliyorlardl. İlk stajımı toplum sağliğı merkezinde yaptım. Bir de büyük bir hastanede 4. sinıf stajımı yerine getirdim. 3. sınıfta sadece acilde çalıştım ama 4. sınıfta 3 ay arayla bölüm değiştirdik. Kadın Doğum, Hematoloji, Yoğun Bakım, Acil Serviste çalıştım. Hastanenin (Trabzon) ĕgitim hemşiresi yerlerimizi belirliyordu. Staj notunu servis sorumlusu veriyordu. Biz staj defterine sadece gün içinde yaptı̆̆ımız girişimleri yazıyorduk. Gördüğümüz ilaçları yazıyorduk. Sonra her ay toplanıp o ay gördüğümüz ilaçları, etkilerini, yan etkilerini tartışıyorduk. Onları farmakoloji için ezberliyorduk. Invaziv (girişimsel) işlemlerde neler yaptı̆̆ımızı ögreniyorlardı. Stajda acilde çalışırken enjeksiyon yaptım, kan aldım, damar yolu açtım. Hatta sütur (dikiş) bile attım. Acildeki servis hemşiresi benim hevesimi görünce beni ayrıca eğitmişti. Ama tüm ögrenciler her işlemi yapabiliyordu. Pansuman da yapıyorduk. Ama ben bebeğe kafadan damaryolu bile açtım. Başımda hemşire durdu işlemi yaptım. Illaç uygulaması da yapıyorduk yalnız başımıza. Ilaçları aslında bizim hazırlamamamız gerekirken biz hazırllyorduk. Çay demleyip, kantinden simit almak gibi ayak işleri de yapıyorduk. 3. sınıfta spanç yapıyorduk, kan numunesi getir götürü yapıyorduk. Hasta bakımı da yapıyorduk. Ama servisine göre değişiyordu. Tanımıyorlarsa çok fazla ayak işi yapıyorduk. Sadece tansiyon alabiliyorduk. Özellikli işleri yaptırmıyorlardı. Okul dönemi stajları daha ağırdı. Daha büyük hastanede çalışıyorduk. İşe yarar 3 stajyer olurduk. Diğerleri kaçardı. Odalarda uyuyan stajyerler bile vardl. Notlara bunu yansitıyorlardı ama öğrenciyi hiç stajdan bırakmıyorlardı” (Yağmur, yaş 22).

Başka bir mezun da:

"Staj yerini okul ayarliyordu. Bulunduğumuz ilçenin devlet hastanesine gidiyorduk. Bulunduğum yerde tek hastane vardı. Her ay staj yeri değişiyordu. Hastane içindeki tüm bölümlerde çalıştım. Notlar uygulama dersine ekleniyordu. Hocalarımız bize hasta incelemesi yaptırıp staj defterimize 6-7 tane hasta yazdirlyorlardı ve sorular soruyorlardl. Hoca(lar) servise gelip hastaya bakıyor, doğruluğu teyit edince ona göre not veriyorlard. 11. sınıftayken ilaç veriyorduk hastalara yalnız başımıza, ama damar yolu açmamıza izin yoktu. 12 sınıflar damaryolu açıp pansuman yapıyorduk. Getir götür işlerinin hepsini biz 
yapıyorduk aslında servis dışına çıkmamız yasak olmasına ră̆men. Başka bir hastaneye gittiğimde yaz stajında hemşirelerle birlikte kendi işlerimizi yaptık. Hemşire sayısı da ögrenci sayısı da yeterliydi. (Güneş, yaş 22).

Staja kaçıncı sınıfta başlıyordunuz sorusuna öğrencilerden değişik yanıtlar gelmiştir. Bir mezun "3. sinıfta başliyoruz staja. 3. sinıfta haftanın 2 günü, 4. sinıfta haftanın 3 günü staj yaplyorduk. Tüm gün yapıyorduk. Yaz stajımız da vardı. Sabah 8, akşam 16'ya kadar yaplyorduk” (Yağmur, yaş 22) derken başka bir mezun, "Biz stajda akşam 15.30'a kadar kalıp sonra okula geçiyorduk. Orada da iki ders yaplyorduk. 3. sinıfta 2 gün, 4. sinıfta 3 gün staj yapıyorduk. Yaz stajımız da 36 işgünüydü. Hem 3. sinıf hem de 4. sinıfta yaz stajımız vardl. Yani mezun olmadan önce yaz stajı yapmış oluyorduk" şeklinde yanıt vermiştir (Güneş, yaş 22).

Staj süresi ve sürecine ilişkin SML öğretmeni:

"Artık hemşire yardımcilığl olduğu için mezuniyet unvanı, sadece 12. sinıfta staja gidiyorlar. 2 dönem haftada 3 gün staja çıkıyorlar. Yaz stajı da artık uygulanmıyor, kaldırlld. Yardımcıllğa döndüğ̈̈ için staj günlerini ve sürelerini azalttılar. Dönem biter bitmez beceri eğitimi sinavina giriyorlar, kazanan diploma almaya hak kazaniyor. Eskiden önce beceri eğitimi sinavl yapıp sonra yaz stajı uyguluyor ve sonrasinda mezun ediyorduk öğrenciyi. Artık sistem değişti. Beceri eğitimi sorularını biz hazırliyoruz. Bir kısmı sözlü, bir kısmı da uygulamalı olarak yapıliyor. Genelde geçiyorlar. Staj yerinin ayarlanmasında küçük yer olduğu için sorun olmuyor. Öğrencimiz de az. Tek Sağllk Meslek Lisesi var, iki hastane var o yüzden sorun olmuyor" demiş, öğretmene okuldaki pratik eğitimin nasıl verildiği, malzeme durumu sorulmuştur. Öğretmen "Malzemelerimiz yeterli değil. Okulumuz küçük bir okul olduğundan malzemede sıkıntımız var. Ara ara bütçe geliyor okula. Ondan acil ne alabilirsek, hangi maketlere, hangi malzemelere ihtiyaç var, meslek dersleri öğretmenleri toplaniyor ve acil ihtiyaç listesi hazırlyyor ve para neye yeterse onu allyoruz" demiştir (Görüşmeci 17, Öğretmen SML).

TOML öğretmenleri staj süresine ilişkin olarak genelde İl Milli Eğitim Müdürlüğünün takvimine göre belirlenen 4,5 ay ile 6 ay arasında bir staj süresinden söz etmişlerdir.

"Nisan ayında derslerimiz biter, Ekim ayında başlar. Yaklaşık 6 aylık bir süre staj oluyor. Her il bu staj sürelerinin başlangıç ve bitişini kendisi belirliyor...yayınlıyor... Staj 10. sinıfta başliyor, 11. sinıf, 12. sinıfları kapsiyor. 11. sinıfta öğrenci staja gidiyor, döndüğünde 12. sinıf olmuş oluyor. Nisan'a kadar yine derslerini allyor. Bizde yoğunlaş̧tırılmuş bir staj dönemimiz var... 6 ayllk bir staj sürecimiz var...12.sinifi bitirince de mezun oluyor öğrenci... Diğer meslek liselerindeki yaz stajı uygulaması bizde normal staj sürecidir. Okulun otelinde de Nisan-Ekim ayları dışında usta ögrreticilerimiz çalışmaya devam ediyor" (Görüşmeci 13, Öğretmen TOML).

Staj süresinin uzun olması ve öğrencilerin o bölgede kalması nedeniyle öğrencilere dinlenme süresi verilip verilmediği sorulmuş, tüm öğretmenler öğrencilerin günlük 8 saat çalıştığını ve haftada bir gün de hafta tatilleri olduğunu, işletmelerde imza kontrolü yapıldığını ve devamsızlık yapan öğrencilerin işletmeler tarafından okula bildirildiğini söylemişlerdir.

Bölümde çalışanlar staj sürecinde yardımcı oluyor muydu sorusuna SML mezunu (Seher, yaş 24) şu şekilde yanıt vermiştir: 
"Çok farklı kişiler vardı. Bazıları gerçekten de işi öğretip bizi yönlendiriyorlardl. Bazıları da kâğıdı poşet dosyaya koyarken bile doğru koyacak mı diye bizi izlediği için mobing gibi hissettim. Bazı öğrencileri tutuyorlar, onlart yönlendiriyorlardı. Başka bir görevli ise herkes her işi yapabilir deyip yapmayan ögrencilere de uygulama yaptırıyordu. Staj notlarını bölüm şefi veriyordu. Hocalarımı da bizi izleyip rapor yazlyordu. Okulda da sorular soruyorlardı. Çekimi zor olan işlemleri özellikle soruyorlardı yaptınız mı diye. Stajda staj dosyası dolduruyorduk. İlk giren hastanın ne olduğunu, hastaya yaptığımız işlemleri yazıyorduk. Teoride öğrendiklerimiz üzerinden yorum yapıyorduk. Yaz stajı sonrası bu defteri hocalarımız kontrol ediyordu. Okul döneminde sadece imza attyorduk, defter doldurmadık. Kartlarımız da girişte çıkışta basıyorduk”. Öğrencilerin staj sürecinde temel denetimi işyerindeki kişiler tarafından yürütülmektedir.

Staj süreçleri nasıl daha iyileştirilebilir sorusuna SML mezunu (Seher, yaş 24) "Staj gerekli. Çünkü alana çıtktığında kabiliyetlerin daha fazla gelişiyor. Bir de kendi okulunuzun hastanesinde değil de diğer yerlerde stajyerlerin daha bilgili olduğunu düşünülebilirler. Bazlları da öğrenciye güvenmek istemiyor. Alandan kişilerin işte çalıştırılması önemli. Onlar da uygulamayı stajda öğreniyorlar. Alaylılar çok bilgili değiller". Diğer bir görüşmeci ise "Stajda bize iyi davrananlar da kötü davrananlar da vardl. Bazı tembel çalışanlar biz her işi yaptığımız ve sorumluları onlara kızdı̆̆ için bize kötü davranıyorlardl. Kendilerine çay getirtiyorlardı. Mobing yaptyorlardl. Kahvaltı yaparken bizi çağırmıyorlardı" diyerek staj uygulamalarında zaman zaman baskıya maruz kaldıklarını ifade etmiştir (Güneş, yaş 22).

Mobilyacıllk bölümünde okuyan bir mezun ise "Stajda iyi bir işletmede çalıştım. Bana pek çok iş yaptırdular. Ben de zaten bu meslekte devam etmek istediğim için bir şeyler ögrenmeye çalışıyordum. Beni sevmişlerdi. Bazen hafta sonu da çağırıp bana karşıllğında harçlık veriyorlardı. Kötü davranışla karşılaş̧madım. İşs olunca beraberce geç saate kadar kaluyorduk. Ama hakkımı hep verdiler" diyerek staj süresinin dışında da işyerinde çalıştığını ifade etmiştir (Rüzgar, yaş 21).

Endüstri Meslek Lisesi ve Turizm ve Otelcilik Meslek Liselerinde okulların atölyelerinde veya işletmelerinde üretim yapıldığı için okulların döner sermaye geliri vardır. Okulların bünyesindeki atölye ve işletmelerde öğrenciler beceri eğitimi yapmaktadır. Bu nedenle okullardaki üretim sürecine ilişkin sorular sorulmuştur. Öğrenciler okulun otelinde çalıştıklarını ve bunun karşılığında bir miktar ücret aldıklarını, bunun değişkenlik gösterdiğini ifade etmişlerdir. Mobilyacılık Bölümü öğrencileri de okulun atölyesinde bazen sipariş üzerine bazı ürünler ürettiklerini, bunun karşılı̆̆ında ücret verildiğini ifade etmiş̧lerdir. Öğretmenlerin açıklamaları şu şekildedir: "Bizim okulumuzda bulunan otelimiz bir işletme olarak görülüyor ve ögrrencilerimizi de dışarıdaki staj yerlerine nasıl yerleştiriyorsak staj yeri olarak oteldeki bölümlere yerleştiriyoruz. Tipkl diğer işletmelerde yapılan uygulamalar; soğuk, sıcak, ara sıcaklar, ana yemekler diğer işletmelerde olduğu gibi burada da aynı şekilde öğreticiler eşliğinde uygulanıyor. Konaklama bölümündeki ögrencilerimiz de kat hizmetlerinde, ön büroda stajlarını yapmış oluyorlar" (Kadriye, yaş 44).

Bir öğretmen de süreci şu şekilde özetlemiştir:

"Usta ögretici denilen ve yine bizim mezun öğrencilerimizden aldığımı kişiler var bu otellerde. Sektörde çalışıyor bunlar. Her bölümün başında birer iki kişi çalışıyor. 10. sinuftan 12. sinifa kadar her sene 2 hafta uygulama otelinde ögrrencilerimiz kendi alaninda çalışlyor. Buradaki çalışmasına göre staj notu veriyoruz. Öğrenci ben uygulama otelinde 
çalışacağım, buradaki şefleri göreceğim diyor. Bunların içinden biz seçiyoruz ve yaz döneminde nasıl Antalya'ya staja gidiliyorsa burada da seçtiğimiz 5-6 öğrenci staja kalıyor. Uygulama otelinde parça başı sisteminin getirdiği karın \%30'undan az olmamak üzere belli bir pay veriliyor. Döner sermayeden maliyetler düşüldükten sonra en az üçte biri öğrenciye verilmek zorunda. Ĕgitim öğretim döneminde bu ödeme yapllyyor. Staj döneminde de asgari ücretin \%60'ı veriliyor. Bunu işveren veriyor. Öğrencilere çalıștı̆̆ yerde müssteriler tarafindan bahşiş de veriliyor. Ödeme banka üzerinden yapıllyor. Elden ödeme yok" (Toprak, yaş 44).

Okullardaki üretim süresinin yoğun olduğu bölümlerden birisi de mobilya ve iç mekân tasarımı yapan bölümdür. Bu bölümdeki öğretmen süreci şu şekilde aktarmıştır:

"Atölyede 10. sinıfta takım kullanmaya yönelik eğitim veriliyor. Oradan çıkan ürünler kullanılabilir ürünler değil. Numune, örnek birleştirmeler, konstrüksiyonlar, el aletlerini kullanıp ellerinin alışması için yaptıkları işler. 11. sinıfta biraz daha ürüne dönük eğitimler oluyor", 'okul bundan gelir elde ediyor mu?' Gelir olmuyor. O ürünleri satmiyoruz. Okulun ihtiyaçlar yapıllyor. 'Kamu kurumlarına filan sipariş üzerine ürün üretmiyor musunuz?' $O$ şekilde döner sermayeden MEB ya da Il Milli Eğitim Müdürlüklerinden sipariş gelirse herhangi bir donatı siparişinde öğrenciler de katkda bulunuyor, ayrıca ücret de alıyorlar. Ücretin miktarı değişken. Herhangi bir üründe işçilik oranı var. Bu işçiliğin belli bir yüzdesi ögrrenciye, belli bir yüzdesi çalı̧̧an personele, belli bir yüzdesi idari personele, belli bir yüzdesi de idari işletmeye bölünüyor. Yönetmeliğe göre belirleniyor. Üretim var ama sipariş varsa. Sipariş aramıyoruz. Aslinda bu döner sermaye işinde ögrenci daha iyi yetişiyor. Yönetmelikte de gerçek üretimin içerisinde çalışma koşulu yerine getirilmiş oluyor" (Bora, yaş 49).

\section{5.Çalışma koşulları ve ücret}

Meslek lisesi türüne göre öğrencilerin çalışma koşulları ve ücreti farklılaşmaktadır. Stajyerlerin ücreti asgari ücretin yüzde otuzu olup, Turizm ve Otelcilik Meslek Liselerinde ise asgari ücretin yüzde altmışı kadardır. Ancak bu işçilerin iş görme karşılığı aldıkları ücret değil bir nevi sosyal ücret niteliğindedir. Diğer yandan okullarda atölye veya işletme varsa buralarda döner sermaye geliri yaratılmakta bu gelirden öğrencilere de pay verilmektedir (Kablay, 2019).

Stajdaki çalışma koşullarına ilişkin sorulan soruya öğrencilerin verdiği yanıtlar bazı alanlarda uygulamaların benzer olduğunu, bazı alanlarda ise farklılaştığını göstermektedir. Öğrencilere staj süresi, çalışma süresi, yapılan işler hakkında sorular sorulmuştur. Alınan yanıt:

"Staj başlamadan da hocalarımız bizi uyum sağlayalım diye hastaneye götürüyordu. Ama ilk yıl kesinlikle staja çıkmadık. Teorik eğitimi tamamladıktan sonra staja çıktık. Yaz stajı yaptık. Herkes yapmak zorundaydı ama belli ortalamayı tutturan yaz stajına çıkıyordu. Yoksa sonraki yll bekliyordu...Değişik bölümlere değişik gruplar staja gidiyordu. Haftanın en az 3 günü hastanede oluyorduk. Geri kalan zamanda okulda teorik eğitim allyorduk. Yaz stajı standarttı. Ama klş döneminde ögrenci saylsı fazla, staj yapılan yer sayısı az olunca süreler değişiklik gösterebiliyordu. Büyük şehirde (İzmir) aslinda staj yaptım ama staj yeri bazen sorun oluyordu. Okulda staja yönelik eğitim de veriliyordu. Hocalarımız hastanede bizimle de çalışıyordu. Dolayısıyla anlattıkları ile uyguladıklarımız uyuşuyordu. (Seher, yaş 24). 
Staj yerlerinin ayarlanmasına ilişkin soruya öğretmenin verdiği yanıt: “Örneğin Antalya'dan örnek veriyorum... Otel 15 ögrenci istedi... protokol imzalanıyor. 5 otelle anlaşıldı örneğin. Kaç ögrenci alıyor. 60 öğrenci alıyor. Bunun anlaşmasını okul yapar...Yakın çevrelerdeki yerleştirmelerde; yakın ilçelerde ögrenci oturuyorsa yakın yerdeki işletmeye yerleştiriliyor. Nedeni hem yol yakın olsun hem de mezun olduğunda iş bulabilmesi açısından avantaj să̆lıyor” (Kadriye, yaş 44).

Günlük staj süresi maksimum 8 saattir. Stajda bazı işyerlerinde yemek kurum/işletme tarafından verilirken bazılarında karşılanmamaktadır. TOML öğrencileri otellerde konaklayarak çalıştıklarından yemek, barınma gibi giderleri işverence karşılanmaktadır. $\mathrm{Bu}$ turizm merkezlerinde işverenler stajyerleri 8 saatten uzun çalıştırabilmektedir. Fazla çalıştırmalara ilişkin ücret de verilmektedir. Ancak özellikle bu öğrenciler stajdan ziyade iş görmekte ve işçileşmektedirler (Kablay, 2019; Kablay, 2021).

Öğrencilerin stajdaki çalışma sürelerine ilişkin TOML öğretmenlerinin verdiği yanıtlar şu şekildedir: "8 saat günlük staj yapılıyor...'fazla çalışma yapılıp yapılmadığı sorulduğunda' imzalanan protokollerde (işletmenin müdürü ile okul yönetimi arasında) ögrencilerin çalışma süreleri belirleniyor. Hiç sürenin aşıldı̆̆ına dair tatil bölgelerinde şikâyet almadık. Zaten oteller bu işi profesyonel olarak yapıyor ve sürekli Türkiye'nin dört bir yanından stajyer ögrencilere staj yaptırıyorlar. Bu sistemi oturtmuşlar artık” (Kadriye, yaş 44).

Stajlarda öğrencilere ayak işi diye tabir edilen; getir götür, temizlik, çay demleme, getirme işlemleri yaptırılmaktadır (Kablay, 2019). Ayak işlerinin yanı sıra stajyerlerin normalde sorumluluğunda olmayan, hatta yapmaması gereken bazı işlerin kimi zaman gözetim dahilinde olmadan stajyerlere yaptırıldığı öğrenilmiştir. Örneğin SML'de artık yardımcı eleman yetiştirildiğinden invaziv girişim yetkisi olmayan ve bunun eğitimi verilmeyen stajyerlere bölüm çalışanları tarafından bu işlerin öğretilerek yaptırıldığ 1 öğrenilmiştir. Bir mezun acilde çalıştığı bir dönemde sütur (dikiş) attığını dahi söylemiştir. Öğrencilerin tek başına ilaç uygulaması da yasak olmasına rağmen çoğu zaman bölümlerde yeterli eleman olmamasından dolayı servislerin tüm takip işleri (tansiyon, nabız, ateş ölçme) ve ilaç uygulamalarının öğrencilere bırakıldığı staj uygulamaları vardır. Bu durum hem ögrenciler hem de hastalar açısından risk yaratmaktadır.

Stajda en sık yaşanan sorunlara ilişkin bir öğretmenin verdiği yanıt:

“Çocuk alanında çalıştırılmayabiliyor. Örneğin tek bir yerde çalıştırılıyor. Oysa biz rotasyon istiyoruz... konaklama alanında ĕ̌itim alan öğrencilerimiz meydan diye tabir edilen genel alanların temizliğinde çalıştırllıyor. Halbuki biz başta öğrencilerin konuşmamızda bir ay meydanda çalışmışsa, bir ay ofis temizliğinde, ondan sonraki ay odalarda çalışmalar yönünde istekte bulunuyoruz. Zorlamayla son 15 gün-20 gün bu yapıllyor. Çünkü bunlar(a) ucuz işgücü olarak, her işi yaptırabileceğimiz insan gözüyle bakllyyor. Otelcilikte şu anda Kırgızistan'dan, ya da Kafkas ülkelerinden dünya kadar işçi geliyor. Bazı otellerde Suriyeli işçiler de var. Personel sıkıntısı çekildiği için bu ülkelerden bile işçi çalıştırıllyor ve ögrencilere de işçi gibi davranılıyor. Bir de bu sektörde şu düşünce var; biz size ögrenci yetiştiriyoruz, istediğimiz gibi bu öğrencileri şekillendirme şansına da sahibiz... Ö̆grencilerin bu işi sevmemelerine de neden olabiliyorlar. Oysa ögrenciler bu işi sevseler bu işe devam edecekler. Bir de işlerin çoğunda 7 ay otel açıksa, 5 ay kapalı. İşletmelerin çoğu sinırlı zaman aralığında çalışıyor, hizmeti depo edemezsiniz. Bugün 1000 odanız varsa, yarın 2000 oda satamazsınız. Dolayısıyla en kısa zamanda, en çok kar elde edilmek isteniyor. Bundan dolayı da çalışanlara verdikleri ücret az. Mevsimlik çalıştı̆̆ için 
işçi bulamiyorlar. Belli bir zamandan sonra mezun ögrencilerimiz de, kendi iş̧̧ileri de düzenli bir iş bulduktan sonra bu sektörden kaçıyor. Baş̧a işi seçiyor...ülke için turizm önemliyse, dolaylsıyla burada çalışanlara, ögrenciler de dahil olmak üzere bu insanlara, hak edilen değeri vermek zorunda, hem Bakanlık hem de işletmeler" (Toprak, yaş 44).

Başka bir TOML öğretmeni ise (Ayşe, yaş 41) işletmelerin hepsinin aynı kefeye konulamayacağını mesleği sevdiren işletmeler de olduğunu, öğrencilerin bu işletmelerde birkaç sene çalışıp arabasını bile aldığını belirtmiştir.

TOML'de okuyan öğrencilerin özellikle ailelerinden uzak bir yerde staj yapması ve korumasız olması nedeniyle psikolojik ya da cinsel tacize, şiddete uğrayıp uğramadığı sorulmuştur. TOML mezunları psikolojik olarak özellikle mutfak bölümlerinde ve kat hizmetlerinde bazen sıkıntı yaşadıklarını belirtmişler, cinsel tacize uğradığını söyleyen mezun olmamıştır. Öğretmenlerin konuya ilişkin düşünceleri şöyledir:

"Antalya'daki işletmelerde cinsel taciz olayına hiç rastlamiyoruz. Ben de meslek lisesi ögrencisiydim, bu tip sorunlar görmedim. Ama mesela ben de ögrenciyken mutfakta çalışmak hiç istemezdim. Çünkü mutfaktaki ustalar inanılmaz küfürlü konuşuyorlardl. Şimdi onun da biraz kırıldı̆̆ını görüyorum. Öyle ustalar yok mu? Var ama sayıları azaldl. Eğitim seviyesi arttıkça bu tip sorunlar azaldı. Eskisi gibi baraka türü yerlerde kalınmiyor artık. Yerine göre klimalı 2-3 yatağın olduğu odalarda kalınıyor. Şartlar da düzeldi. Daha düzgün alanlarda kalyyorlar." (Bulut, yaş 46). Diğer bir öğretmen de "Ben bu okula geldiğimde çok atıl lojman vardl. Ama her geçen gün şartlar düzeldi. Biz de işletmelere ögrencileri gönderirken şartlarına bakiyoruz, işletme seçiyoruz. Bizim öğrencilerimizi özellikle istiyorlar. Karadeniz çocuğunu (Ünye), kırsal bölge çocuklarını saygılı diye özellikle istiyorlar. Antalya'daki yereldeki okulun ögrencisini istemiyor saygısız diye. Aile terbiyesi görmüs diye. Biz de ögrrencilerimizi staja hazırlyyoruz. Ne durumda nasıl davranacaklarını da öğretiyoruz" (Ayşe, yaş 41).

Ender ve Lordoğlu'nun (1993: 50) çıraklar üzerine yaptıkları araştırma da işverenlerin çırak (örneğimizde stajyer) seçerken önem verdikleri konuların başında öğrencinin tavır ve davranışları gelmektedir. Geleneksel şekilde ister çırak olsun, isterse de stajyer olsun "saygı, terbiye ve sadakat" beklentisi üst düzeydedir. Yağcı ve arkadaşlarının (2021) seyahat acentesi sahibi ve yöneticileri ile yaptıkları çalışmada da benzer şekilde stajyerlerin gelişime açık olması, "söz dinlemesi, takım çalışmasına uyumlu ve güler yüzlü olması" istenmektedir. İşverenler itaatkâr stajyerleri tercih etmektedir. TOML öğretmenin de belirttiği gibi küçük yerleşim yerlerindeki öğrenciler daha saygılı ve itaatkar oldukları için tercih edilebilmektedir.

Öğrencilerin otellerin hizmetlerinden faydalanıp faydalanamadıkları sorulmuş, öğrenciler genellikle otelin hizmetlerinden faydalanamadıklarını ifade etmişlerdir. Öğrencilerden biri "Hocam, çoğu zaman yatağın yüzünü zor görüyoruz, ne hizmeti? Ama neyse ki konakladı̆̆ımız odalar iyiydi" (Ali, yaş 22) şeklinde konuşmuştur. Bir öğretmen ise "Havuzdan yararlanma gibi hizmetlerden faydalanmay çok göremiyoruz, ama bazen tekne turlarına götürebiliyorlar. Kendileri halk plajına gidiyorlar. Bazı işletmeler de ayın personeli seçtiği kişiye oteli bir gün müşteri gibi kullanma ödülü verebiliyorlar. Hepsi değil ama. Çok iyi çalıştı̆̆ın için bir gün bizim müşterimiz ol diyor" bu uygulamanın nadir olduğunu ifade etmiştir (Bulut, yaş 46). Başka bir öğretmen ise "Buradaki bir işletme de mutlaka öğrencilerin doğum gününü kutluyor. Bu da ögrenciyi motive ediyor, işletmede aile olma hissini veriyor. Tartı̧̧ma gibi şeyler olabiliyor ama o 
durumda biz araya giriyoruz. Işsletmelerde şiddet olayı ile karşılaşmıyoruz" diyerek işletmelerle öğrenciler arasındaki ilişkilerin genelde iyi olduğunu ifade etmiştir (Kadriye, yaş 44).

Tablo 1'de de görüldüğü gibi öğrencilerin ücreti asgari ücretin \%30'undan az olamaz (MEB, 2018). Ancak bu ücret sosyal ücret niteliği taşımaktadır. TOML öğrencilerine ise asgari ücretin en az $\% 60$ 'ı kadar ücret ödenmektedir. Ayrıca daha önce de belirtildiği gibi döner sermayesi olan okullarda yapılan işe göre bir miktar katkı payı alınabilmektedir.

Öğrencilerin ücret ve diğer ödemeler veya haklar konusunda verdiği yantllar: "Stajda ücret aldık. Ücretimiz sadece yaz stajinda verildi. Okul döneminde ücret almadık. Çünkü o ders olarak gözüküyordu" (Seher, yaş 24)". Bir diğer görüşmeci (Yağmur, yaş 22) "Stajda bize yemek veriyorlard a ama yol ücretini kendimiz karşıllyorduk" derken bir diğeri de (Güneş, yaş 22) "Hepimize yemek vermiyorlard. Bir dönem bir gruba, diğer dönem diğer gruba yemek veriliyordu. Yemek verilmeyenler kendisi yemek olayını çözzüyordu. Ücret asgari ücretin \%30’u ya da 1/4’ü kadardl. Ama düzenli yatmiyordu. 3-4 ayda bir veriyorlardl. Biz sürekli ne zaman vereceksiniz diye gidip gelip soruyorduk. Yattığında da 3 aylık yatıyordu ama 50 lirasını, 100 lirasın keserek yatırıyorlardl." demiş̧ir. Bu durum kamu kurumlarında bile yemek konusunda ortak bir davranışın sergilenmediğini göstermektedir.

Ücretinin bir dönem verilmediği için mezuniyet sonrası dava açtığını söyleyen bir mezun da olmuştur: "Bizde 3. sinıfta hastanenin döner sermayesi yok diye ücret vermediler. Sigortalarımız yatırlldl. 4. sinıfta vermeye başladılar. Aylı olarak bankadan çekiyorduk. Sonra mezun olunca ögrenciler imza toplayarak staj ücreti vermedikleri döneme ilişkin dava açtık. Dava ile toplu olarak iki bin küsur lira ücretimi aldım. Mezuniyetten 2 yll sonra aldım" (Yağmur, yaş 22).

Öğretmenlerin ücret ve diğer ödemelere ilişkin açıklamaları:

"Sözleşmede asgari ücretin 1/3'ünden az olmamak üzere hüküm var. Bu miktardan yüksek verenler de var. Büyük işletmeler, işi iyi olan atölyeler veriyor. Geçen yll örneğin alt tavan 450 lira idi. 1000 lira alan ögrenci de vardl. Parayı elden veriyorlar. Devletin stajyerler için işletmelere teşvikleri var. Dolayısıyla işletmenin cebinden çok az para çıkmış oluyor. Hem de işçi yerini tutmasa da ögrenciler de hayli çalışlyor. Ücretin verilmediğine dair şikâyet olursa bunu nasıl çözüyorsunuz?" "İşyeri ile biz konuşuyoruz, okul idaresini devreye sokuyoruz. Daha da ödemezse işyerini değiştirmesini istiyoruz... Herhangi bir yere hiç şikâyette bulunmadık. Ama bunlar çok münferit. Çok az kişide bazen gecikme oluyor" (Bora, yaş 49).

SML öğretmeni ise "Staj için ödeme yapıllyor. 500 küsur lira. Tam tutarını bilmiyorum, ama asgari ücretin \%30'u kadar bir ödeme yapllyyor. Ödemeyi staja gittikleri hastane yapıyor. Ödeme öğrencilerin banka hesaplarına yatıyor" (Bahar, yaş 46).

Stajda öğrencilerin kontrolünün nasıl sağlandığına ilişkin soruya öğretmenlerin verdiği yanıtlar:

"Biz de uzak yerlerde de olsa gideriz. Koordinatör müdür yardımcımı var, o ayarlamaları yapıyor. Bu süreçte ayda bir, 15 günde bir görevlendirildik. Sonra öğretmen sayımızda azalma oldu. Ayda bir ya da 3 haftada bir gibi gidiyoruz. Zaten ...yanımızdaymıs gibi öğrenciyi sürekli arıyoruz. Aynı şekilde işletme yetkililerini de arıyoruz...Herhangi bir problemleri olduğunda whatsupptan mesaj attyorlar. Bize ulaşıldiğı gibi, biz de yetkililerle 
irtibatı sağlayıp orada sorunu çözüyoruz. Öğrencimiz orada da kendini güvende hissediyor. Biz otele gittiğimizde, bekçiden, restoran şefine kadar herkesle iletişime geçip bilgi alıyoruz. Hepsinin telefon numarası bizde kayıtll. Staj sürecinde disiplin suçu işlerse bunu da değerlendiriyoruz" (Toprak, yaş 44).

"Örneğin gece öğrencimiz mesaj atmış, ailesinde sorun varmış. Ertesi gün işletme yetkilisi ile görüşüp öğrenciye izin aldik. Dört beş okula öğrenci gönderiyorsak örneğin bir haftalığına öğretmen gönderiyoruz. O civarda ögrencilerin olduğu her otelde en az 24 saat kallyor ve izliyor. Barınma, pansiyon, çalışması, oradaki arkadaşları ile ilişkiler, gece pansiyona giriş saati konusunda bekçi ile konuşuyoruz. Çalışma saatlerine bakıyoruz. Ögrencilerin müdürleriyle sorunları var mi, hasta olduğunda izin veriliyor mu bunlara bakiyoruz. Ögrencilerin yanındayız ama bir yandan da işletmede öğrenci sorun yaratıyor mu, gece geliş gidiş, arkadaşlarlyla uyumu nasıl buna da bakıyoruz. Meslekte nasıl, ilerliyor mu, bundan bir şey olur mu ona da bakıyoruz" (Toprak, yaş 44).

Sağlık Meslek Lisesi öğretmeninin soruya verdiği yanıt:

"Koordinatör öğretmen olduğumuz için haftada bir gün gidip yoklama allyoruz. Onun dışında kontrol hastane personelinde. Hastaneye gittiğimizde sorumlular ile görüşüyoruz, bir sıkıntı var mı yok mu soruyoruz. Öğrenciler hastaneye gittiğinde hastane kendi kontrolü için imza attırlyor ama biz okul olarak artı imza takibi yapmıyoruz, o eskidendi. Staj defterleri var, onlarl kontrol edip imzallyoruz. Vaka takdimi de artık yapılmıyor" (Bahar, yaş 46).

Staj sürecinin değerlendirilmesi, notlandırılmasına ilişkin öğretmenlerin verdiği yanıtlar, değerlendirme konusunda işyeri çalışanlarının etkili olduğunu göstermektedir.

"Staj bitiğinde öğrenciyi okulda uygulamaya sinavina allyoruz. Bir de işletmelerde ögrencilerin yaptıklart rapor ediliyor. Onlar imzallyor staj defterini. Buradaki sinavdaki notun \%80'inin alyyoruz, bir de işletme ayrica not veriyor. Onun da \%20'sini allyoruz. Öğretmenin daha önceki ylllardaki değerlendirmesi gibi birçok kriter bir araya geliyor. Staj notu e-okulda ders notlarının arasında gözüküyor. Bu not çok önemli. Örneğin ögrencinin beceri notu 90, diğer notlarl 45-50 bile olsa teşekkür, taktir alabiliyor. Çünkü kredisi var (yüksek)" (Toprak, yaş 44). Başka bir TOML öğretmeni ise "Staj notlarının kredisi yüksek olduğundan okulda haylaz olan öğrenci bile işletmede çok iyi çalışlyor. Beceri eğitiminde en haylaz ögrenciden bile çok güzel geri bildirimler geliyor" (Kadriye, yaş 44).

\subsection{IŞ güvenliği}

Demirdağ ve diğerlerinin (2018) bir devlet hastanesinde öğrencilerin, kesici delici alet yaralanmalarında bir yıl içinde yaralanma sıklığına ilişkin yaptıkları çalışmada; yıl içinde gerçekleşen 30 kesici-delici alet yaralanmasına maruz kalanların \%10'unun hekim, \%23,33'ünün hemşire, \%3,33'ünün sağlık teknisyeni, \%13,33'ünün temizlik personeli ve \%50'sinin ise stajyer hemşireler olduğu belirlenmiştir. Yaralanmalar; öğrencilerin kan alırken kesici-delici alet kutusunu yanlarında götürmemeleri ( 3 olay), dikkatsizlik ve bilgi eksikliği (10 olay), hastanın ajite olması ( 2 olay) gibi nedenlerle gerçekleşmiştir. Yaralanmaların \%93,3'ü iğne ucu yaralanması olup iş güvenliği açısından daha da sorunlu olan durum yaralanmaya neden olan iğnelerin \%96,6'sının 
kontamine (kullanılmış) iğne olmasıdır. Üstelik bu yaralanmaların \%10'u kan yolu ile bulaşan hastalığa sahip hastalarda kullanılan aletlerle gerçekleşmiştir. Literatürde de tıbbi bilgi ve deneyimlerin az olmasının yaralanmalara neden olduğu belirtilmektedir. Bu durum iş güvenliği açısından özellikle de riskli iş ve işyerlerine gidenlerin eğitimlerinin daha da önemli oluğunu ortaya koymaktadır. Kurallara uyulmaması; stajyerlerin yaralanmasına, kalıcı bir hastalığa yakalanmasına, hatta ölümüne bile neden olma olasılı̆̆ taşımaktadır. Mert'in (2018) yaptığı bir araştırmada ise stajyer hemşirelerde tecrübesizlikten kaynaklı stresin yoğun olduğu, hemşirelere göre hastaya zarar verme durumundan daha fazla strese girdiği tespit edilmiştir. Stajyer hemşirelerde stres yaratan en önemli olaylar invaziv girişim $(\% 31,1)$, yanlış tedavi veya uygulama $(\% 17,8)$, acil tıbbi müdahale durumu $(\% 17,8)$ olarak tespit edilmiştir. Stajyerlerin teorik bilgilerinin iyi olması ve iş güvenliği ile ilgili bilgilerle donanarak staja çıkmaları durumunda bu stresin de azalacağ ileri sürülebilir. Bu çalışmada yapılan görüşmelerde de SML stajyerlerinin bu tip olaylarla karşılaştıkları, hatalı uygulamalar yapabildikleri tespit edilmiştir. Bu nedenle staj öncesi iş güvenliği eğitiminin verilmesinin yanı sıra riskli uygulamalarda stajyerlerin yalnız bırakılmaması da gerekmektedir. Polat ve diğerlerinin (2016) turizm eğitimi alan öğrenciler üzerinde yaptıkları bir araştırmada da öğrencilerin mesleki eğitimde en çok önem verdikleri konular iş kazaları ve cinsel taciz olarak belirlenmiştir. Öğrencilerin staj süreçlerinde her iki anlamda da güvenliklerinin sağlanması gerekmektedir.

Meslek liselerinde farklı alanlarda eğitim alan öğrencilerin staj esnasında karşılaş̧ıkları iş riskleri de farklılaşmaktadır. SML'de kan ve kan ürünlerinden bulaş, kesici-delici alet ayarlanmaları, röntgen 1şınları, hasta ve yakınlarından şiddet görme başlıca riskler olarak karşımıza çıkarken; EML'de bölüme göre elektrik çarpması, kesici-delici alet yaralanmaları, düşmeler, el-ayak yaralanmaları ön plana geçmektedir. TOML'de ise yiyecek-içeceğe bağlı zehirlenmeler, mutfak çalışmalarında kesici alet yaralanmaları, temizlik malzemelerine bağlı alerjiler, ağır taşımaya bağlı kas-iskelet sistemi rahatsızlıkları, 1slak zeminde düşmeler riskler arasında yer almaktadır.

Son y1llarda stajyerlerin iş güvenliğine ilişkin iki önemli gelişme bulunmaktadır. Bunlardan ilki staja çıkmadan önce verilen iş sağlığı ve güvenliği eğitimidir. Diğer ise stajyerlerin İş Kazası ve Meslek Hastalıkları (IKMH) Sigortası kapsamına alınmış olmasıdır. 6331 sayılı İş Sağlığı ve Güvenliği Yasas ${ }^{10}$ tüm işyerlerini kapsama almasının yanı sıra çırak ve stajyerler dahil tüm çalışanları da kapsama almıştır (md. 2/1). Tüm işyerindeki sağlık ve güvenliği sağlamak işverenin görevidir (md. 4/1). Dolayısıyla işyerlerinde stajyerlerin sağlik ve güvenliğinde de sorumludur. 5510 sayılı Sosyal Sigortalar ve Genel Sağlık Sigortası Kanunu ${ }^{11}$ da 3308 sayılı MEK kapsamında mesleki eğitim gören öğrencileri IKMMH sigortası ile hastalık sigortası kapsamına almıştır (md. 5/1b). Dolayısıyla bu öğrencilerin yaptıkları çalışmalar uzun vadeli sigorta kolları kapsamında değildir.

Yapılan görüş̧melerde iş sağlığ 1 ve güvenliğine ilişkin verilen eğitimlerde bir standart olmadığ tespit edilmiştir. Bazı liselerde bir ders olarak bu eğitim verilirken bazı liselerde ise seminer olarak verilmektedir. Eğitimde standart genel bilgilerin yanı sıra alanda karşılaşılabilecek riskler de yer alabilmektedir.

Öğrencilerin bir kısmı iş güvenliğine ilişkin eğitim aldığını söylerken, alınan eğitimin niteliğinin neredeyse tüm okullarda farklı olduğu belirlenmiştir. Örneğin; bir mezun iş güvenliğini ders olarak

\footnotetext{
${ }^{10}$ Kabul tarihi 20/6/2012, 30/06/2012 tarih ve 28339 sayılı Resmî Gazete

${ }^{11}$ Kabul tarihi 31/5/2006, 16/6/2006 tarih ve 26200 sayılı Resmî Gazete
} 
gördüğünü, sertifika eğitimi almadığını söylerken (Seher, yaş 24); bir diğeri böyle bir ders almadığını, sadece hocaların staj öncesi öğrencileri toplayıp iğne uçları vb. konuda seminer gibi ders verdiğini söylemiş (Yağmur, yaş 22), bir diğeri ise bunu bir ders olarak ikinci sınıfta aldığını ve staj döneminde dikkatli olmasını sağladığını belirtmiştir (Güneş, yaş 22).

Öğretmenlerin iş güvenliği eğitimi ile iş kazalarına ve korunma yöntemlerine ilişkin verdikleri yanıtlar ise birbirine benzemektedir. Bir öğretmenin konuya ilişkin verdiği yanıt:

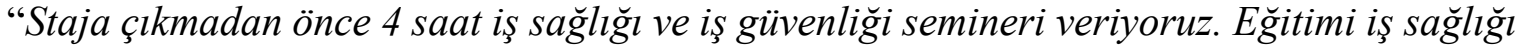
güvenliği belgesi olan varsa onlar, yoksa bu sertifikaya sahip ögretmenler veriyor. Her sene yüz yüze hem velilere hem de ögrencilere bir seminer veriliyor. Sonra da bu semineri aldiklarına dair imza alıp, belge veriyoruz onlara. Konular genel, mesleğe yönelik değil. Takıldıkları noktalarda ustalarına soru sormaları isteniyor. IKMH Sigortasinı 10. sinıftan itibaren okul yaptırlyor. Basit yaralanmalı kazalar oldu. İsveren hastaneye götürülüyor. Birisinde hastane polisi iş kazası formu doldurmamış. Normalde dolduruluyor, okula da gönderiliyor. 3 işgününde Sosyal Güvenlik Kurumuna (SGK) gönderiyoruz. Atölyede olursa kaza aynı şekilde rapor tutulup SGK'ye göndeririz. Atölyede koruyucu ekipman olarak gözlük, eldiven, maskemiz var. Vernik vs. attığında maske kullanıyorlar. Bu malzemeleri okul bütçesinden alıyor. MEB göndermiyor. Eğer yapılan iş döner sermaye işi ise alınacak malzemelerin altına bunlar da yazllıp, çalışan öğrencilere malzemeler dağıtılıyor. Ayakkabı yok. Aktif olarak biz de çalışlyoruz. Vernik, tiner gibi maddeler kullanıyorsunuz. Bunlara iliş̧kin bir bağımlılık sorunu oldu mu, bu malzemeleri nasıl saklıyorsunuz?' Hiç bağımlılık sorunuyla karşılaşmadım. Bu malzemeleri kilitli odalarda sakllyoruz. Ihtiyaç olunca da kendimiz çıkarlyoruz. Öğrenciye anahtar vermiyoruz ve uygulamayı açık havada yapıyoruz. Yă̆mur yağınca ya yapmıyoruz ya da kapıyı açıyoruz. Her gün vernik kullanmıyoruz. 'Toza vb malzemeye karşı öğrencilerde hastalık gelişen oldu mu hiç?' Alerjisi olan oldu. Velileri ile görüşüp bölüm değiştirmelerini önerdik. Okula girişte bir sağlık raporu alınıyor ama genelde sorunlu olmuyor sağlık raporları" (Bora, yaş 49).

TOML öğretmeni konuya ilişkin şu bilgiyi vermiştir:

“İş sağlığl ve güvenliği (íSG) ile ilgili bir uzman getiriliyor. Tüm staja gidecek ögrencilerimiz 10. sınıfta staja başlamadan önce... atölyelerde bıçak gibi çeşitli aletleri kullanacakları için derslerin başladığı ilk anda... ISG uzmanı gelip konferans salonumuzda

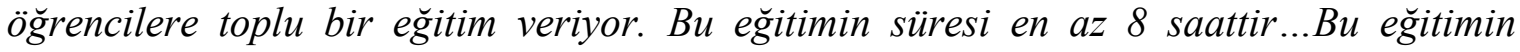
sonunda sınav yapılmıyor, ama iş güvenliği eğitimine ilişkin sertifikaları veriliyor..." (Kadriye, yaş 44). Diğer bir öğretmen ise (Ayşe, yaş 41) C sınıfı iş güvenliği sertifikasına sahip olduğunu ve bu eğitimi zaman zaman kendisinin de verdiğini ifade etmiştir. SML öğretmeni ise (Başak, yaş 36) okulda iş sağlığ 1 ve güvenliğine ilişkin bir eğitim verilmediğini, 9. sınıfta Mesleki Gelişim Dersi olduğunu ve bir ünite şeklinde konunun anlatıldı ğını belirtmiştir.

Öğrenci ve öğretmenlere öğrencilere İKMH Sigortası yapılıp yapılmadığı, yapıldıysa kimin tarafından yapıldığ 1 ve iş kazası durumunda ne yapıldığı sorulmuştur.

Öğrencilerin konuya ilişkin ifadeleri şu şekildedir: "Staja çıkarken IKMH sigortamız okul tarafından yapıldı. Kaza ve hastalık geçirmedik. Bulaş olmadı. Ama bir arkadaşımız kan alırken 
turnikeyi yanlış sırada açtı̆̆ için hastanın biraz fazla kanamasına yol açtı, ama sorun çıkmadl. Hasta şiddetine maruz kalmadık" (Seher, yaş 24). Görüldüğü gibi işlemi yaparken öğrencinin yanında kimsenin olmaması yanlış uygulamaya neden olmuştur.

Bir diğer SML mezunu (Yağmur, yaş 22):

"Kırım Kongolu bir hasta gelmişti. Bizi yaklaştırmadılar. Genel cerrah, enfeksiyon hastalıkları uzmanı çağrıldı. Hastayı izole ettiler. Hastanın kenenin gömülü olduğu yeri deriyle beraber kestiler, o bölge mosmordu. Ama hastayı ilk biz karşılamıştık. Eldivenimiz vardl. Hastalık ögrenilince maske, bone, eldiven, önlük giyildi. En yaygin olarak eldiven kullanıyorduk" demiştir. Bir diğer öğrenci de (Güneş, yaş 22) "Çallşırkken hiç elime iğne batması yaşamadım. Ama bulaşıcı bir grip türü olmuştum. Beni hiçbir yere sokmadılar. İğne batması yaşayan bir arkadaşımız oldu. Dikkatli olmadı̆̆ iç̧in hocalarımız onun staj notunu düşürdüler. Ama iş kazası tutanağı tutulmadl. Takibi yapıldl. Bir de öğrenciye bebeğe vermesi için enjektöre çekip şurup vermişler o da enjektörde diye damardan yapmış. Büyük olay oldu. Bebeği Ankara 'ya gönderdiler neyse ki bir şey olmadı" demiştir.

$\mathrm{Bu}$ örnekte de özellikle ilaç uygulamalarında öğrencinin yalnız bırakılmasının ciddi problemlere yol açabileceği görülmektedir. Aynı soruya öğretmenlerin verdiği yanıtlar da benzeşmektedir.

“Öğrencilere IKMH sigortasını okul yapıyor...Geçen sene başımıza geldi. Öğrencinin ayağ sslak zeminde kaydı düştü. Zaman zaman öğrencilerimizin ergenliğine bağlı hareketlerinden, işletmedeki o andaki çalı̧̧ma yoğunluğundan kaynaklanabiliyor. Çalışma süresi içinde olan her şey iş kazası olarak geçiyor. Dolayısıyla işletme öğrencinin iş kazası bildirimini yaplyor. Bununla ilgili zaten imzalanan protokolde otelde bu işle ilgili bir sorumlu belirleniyor. Iş̧ kazası olunca bütün evrakları dolduruyor, okula bildiriyor. Yatarak tedavi gerektiğinde de işletme gerekli ayarlamalar yaparak ögrenciyi ailesinin yanına gönderiyor. Şu ana kadar bu konuda hiçbir problem yaşamadık" (Kadriye, yaş 44). Başka bir TOML öğretmeni ise duruma ilişkin şu açıklamayı yapmıştır: "Çalıştığı yere göre değişiyor. Mutfak alaniysa eldiven kullaniyor. Ayakkabisina dikkat ediyor. Mutfak alanında hijyen açısından eldiven, bone, maske ve ayakkabıların özellikle sabo tarzı terlik olmasına, giyindiği klyafetlerin uygun olmasina özen gösteriliyor. İş klyafetlerini işletme veriyor ayakkabısına kadar. Kıyafet vermeyen olursa ögrencilerin okulda kullandığ kiyafetler var, bunları kullaniyorlar. Biz kendimiz de atölyelerimizde uygulamalar esnasında bu tür klyafetleri ve araç gereci kullanma zorunluluğu getiriyoruz" (Bora, yaş 49).

SML öğretmeni (Başak, yaş 36) bir sözleşme olduğunu, bu sözleşmeyi okul, hastane ve öğrenci velisinin imzaladığını, İKMH sigortasının okul tarafından yapıldığını, iş kazasına uğrayan öğrenci görmediğini, bu tip olayların büyük şehirlerde çok yaşandığını ve hastanede iş güvenliği ile ilgili kişinin böyle bir durumda devreye girerek süreci yürüttüğünü ifade etmiştir.

\subsection{Mezuniyet sonrast istihdam olanakları}

Mesleki ve teknik eğitim alan bireyler mezuniyet sonrası eğitim gördükleri alanda "teknisyen" sıfatı ile istihdam olanağına sahiptirler. Ancak işsizlik rakamlarının yüksek olması bu mezunları da etkilemektedir. Mezunlar kendi alanlarında yükseköğretime devam etmek istediklerinde ek puan verilmektedir. Diğer yandan bu liselere zorunlu olarak liseye giriş puanları düşük olduğu için giren mezunların alanda iş bulma talepleri de azdır. Bir bölümü üniversitede başka alana kaymakta, bir 
bölümü ise güvenceli olarak nitelendirdikleri güvenlik görevliliği, polislik, uzman askerlik, kargo, market işleri gibi alanları tercih etmektedirler. Aslında meslek lisesinde okumak bir mesleği öğrenmek amacıyla değil lise mezunu olmak için gerçekleştirilmiş olmaktadır (Kablay, 2019). Ayrıca bazı meslek liselerinden mezun olanlar için henüz iş olanağı da sağlanmamaktadır. Örneğin son yıllarda SML'den mezun olanların hemşire unvanı alamıyor oluşu, hemşire yardımcısı olması ve henüz ne kamuda ne de özel sektörde böyle bir istihdam alanının olmaması mezunları umutsuz bırakmaktadır. MEB (2018) verilerine göre de mesleki ve teknik lise mezunlarının \%47,1'i alınan eğitimin iş hayatlarına katkı sağlamadığını düşünmektedir. Her ne kadar mesleki ve teknik lise mezunlarının istihdam oranı genel lise mezunlarının istihdam oranına göre yüksek olsa da meslek lisesi mezunlarının eğitim gördüğü alanda çalışmaması bu algının gelişmesinde önemli bir etkendir.

İstihdamdaki duruma ilişkin bir EML öğretmeninin ifadesi aslında alandaki temel sorunu göstermektedir.

“Çoğu mesleklerini yapmıyor. \%95’i yapmıyor. Daha kolay işlere yöneliyorlar. Mesela güvenlik. Kamuyu da özeli de güvenlik için tercih ediyorlar. Kargo taşımacılı̆̆l, polis, uzman çavuş, tozsuz, talaşsız, gürültüsüz, temiz işleri tercih ediyorlar. Ücret düşünmüyorlar. Çünkü orada asgari ücrete çalışıyorlar. Oysa mesleklerini devam ettirseler daha yüksek ücret alırlar.” 'O zaman neden meslek lisesini tercih ediyorlar.' Çoğu isteyerek gelmiyor. \%95'i istemeyerek geliyor. Puanı başka okulu tutmadığ için geliyor. Zorunlu olarak aile buraya gönderiyor. Fazla tercihleri kalmıyor. Aslında çoğunun okumakta gözü yok. Bazılarında aslında çok güzel yetenek var. Bazıları da 4+4 yüzünden sistemde kalmak zorunda kallyor. Çok iyi esnaf olabilirler, usta olabilirler, servis elemanı olabilirler, ama eğitim sistemi buna izin vermiyor. Onlar da diploma sahibi olmak için meslek lisesine geliyor. Üniversiteye girenler var. Dördüncü sinıfta 200 ögrencimiz varsa bunlardan en az 10 ögrenci 4 yıllık üniversiteye girebiliyor. Bir o kadarı da 2 yıllıklara giriyor. O zaman yaklaşık\%10'u üniversiteye giriyor. Genelde okulun olduğu bölgeden diğer liselere yerleşemeyenler bu okullara geliyor" (Bora, yaş 49).

Bir TOML öğretmeni, öğrenciler çalışmak isterse iş bulabildiklerini ifade etmiştir.

“Yüzde 50-60’ı staj yaptıkları işyerlerine yöneliyorlar. Orası olmasa orada 30 kişi tanıyor. Oradaki şefle iletişimde oluyor. O şef işi bırakıp başka işletmeye giderken beraber çalıştı̆̆ stajyerlerden de eleman götürebiliyor. Birden fazla işletmesi olan oluyor. Çalışmak isteyen ögrencilere iş var. İsletmeler okula gelip kendilerini tanitıyorlar. Eleman ihtiyaçları olduğunda bize soruyorlar. İşletmede staj yapan öğrencileri yerleştirebiliyorlar. Alanda çalışmak istemeyenler düşük oranlarda polis, asker olmak isteyebiliyor. Ama ögrencilerimizin çoğunluğu alanda çalışıyor" (Toprak, yaş 44).

Mevsimlik bir iş, 6 aylık sürenin dışında burada çalışanlar ne yapıyor sorusuna "Aslında Mart'ın sonundan Kasım'ın sonu Aralık'a kadar da sürüyor. 6 ay değil yaklaşık 9 ay gibi çalışılıyor. Bu yıl (2019) Antalya'daki görüşmelerde kış sezonunda da çalışma projeleri olduğundan söz edildi. Alanda olmayanlar polis, uzman çavuş olmak isteyen oluyor ama bunun oranı çok düşük, yüzde on civarında. Askere gidiyor, orada aşçı olarak çalışıp kalabiliyor. Aslında yine kendi mesleğini yapıyor" demiştir (Bulut, yaş 46). Bu durum meslek lisesi alanına göre istihdamdaki durumun değiştiğini göstermektedir. 
"Hemşire ve ATT (Acil Tip Teknisyeni) yetiştirmediğimiz için artık sahada böyle çalışabilecekleri bir alan yok. İstihdam durumu üç yıldır düştü. Atama yok, özel hastanelerde çalışabilecekleri böyle bir birim yok. O yüzden çocuklar üniversiteye yöneliyorlar ve üniversitede bölüm değiştiriyorlar genelde. Öğretmenlik, İngilizce Bölümlerini seçiyorlar, sağllk alanından en çok Paramedik Bölümünü, Ameliyathane Teknisyenliği, Diyalizi seçiyorlar. Genelde başka bölüm seçtikleri ve alanda çalışmadıkları için meslek lisesinde verilen eğitim de boşa gitmiş oluyor. Programın adı değişince aslında derslerin içerikleri de hafifletildi. Eskisi kadar yoğun bir eğitim verilmiyor” Başak, yaş 36) diyerek SML'deki durumu aktarmıştır öğretmen.

Görüşmecilere meslek liselerine ilişkin en önemli sorun ve alana ilişkin çözüm önerileri sorulmuştur. Öğrencilerin yanıtları genellikle istihdam olanağının sağlanması ile okul yerleştirme uygulamasının değiştirilmesi yönünde olmuştur. Tercih ve yerleştirme sisteminin değiştirilmesi görüşmecilerden birisinin de ifade ettiği gibi "hayatlarının azaba çevrilmesini önleyecektir" (Fatma, yaş 21). Özellikle tercihi dışında meslek lisesine yerleştirilen öğrenciler düz liseye gitmek istemektedirler.

Öğretmenler en önemli sorun ve çözüm önerisine ilişkin daha ayrıntılı görüş bildirmiştir. EML öğretmeni (Görüşmeci 19):

"Meslek lisesi eğitimi çok pahalı bir eğitim. Ĕgitim sistemi içerisinde en pahalısı. Çünkü dönem başında metreküp metreküp bir sürü kereste allyoruz, dönemin sonunda bunlartn hepsi odun oluyor. Elektrik harclyoruz, makine kullanıyoruz, makineler köreliyor. Başka ekipmanlar kullaniliyor. Diğer bölümlerin ekipmanları çok pahalı. Bunlar öğrenci alışsın diye ha bire yok ediliyor. Dolaylslyla meslek liselerine ögrenci alınırken sinavla alınsa daha iyi olur. Ben öyle okumuştum ve ben okurken 30 kişilik sinıftan 20'si üniversiteye gitti. Diğer 10'u da muhtemelen iyi bir esnaf olmuştur. Oysa şimdi tam tersi. Zorla ögrrenci getiriliyor ve bunlar eğitilmeye çalışllıyor. Sonuçta 100 kişiden 5 kişi işini ya yapıyor ya yapmiyor. Disiplin yönetmeliği çok gevşek. Yaptırım yok. Sinıfta bırakma yok. Çok esnek. Dolaylstyla zaylf bir sistem. Sinavla olsa, isteyen seçse ülke bütçesine de yük olmaz. Bütçeye inanılmaz bir yük. Oysa diğer Anadolu Liselerinde sadece sinıf, sıra, elektrik ve ögrretmen maaşl var. Bizde bunun yanı sıra, makineler var, bunlar elektrik harclyor, bunların bıçakları köreliyor, arızalanıyor, kullanılan hammadde var. Ve bunların çoğu iş sürecinin sonunda kullanılabilecek durumda olmuyor. Harcaniyor. Sene başında temrinlik (alıştırma) ödeneği altında bir ödenek gelir ve buradan ihtiyaç duyulan malzemeler alınır. Mesleği seçmeyecek öğrenci için gereksiz bir yatırım" (Bora, yaş 49) şeklinde aslında konuyu özetlemiştir.

"Devletimizin bakanlıklarımızın turizm sektöründe belgesi olup işyeri açan A'dan Z'ye hepsinde çalışacak personelin belli bir diplomasinın olması, kriteri taşıyor olması gerek. Okullu olanları yerleştirmeleri gerek. Ucuza olsun diye işi bilmeyenler işe yerleştiriliyor" (Kadriye, yaş 44) diyen bir öğretmen alanda eğitim almamış kişilerin çalıştırılmasının çok önemli bir sorun olduğunu ifade etmiştir.

"Derslerin içeriği için oluşturulan MEGEP ${ }^{22}$ modülünde yer alan dersleri aldlğını gösteren sertifika ile işyerine işe girilebilmesi gerekiyor. Örneğin pastacllık için işe başvurduğunda,

${ }^{12}$ Mesleki Eğitim ve Öğretim Sistemini Güçlendirme Projesi. Ayrıntılı bilgi için Bolat'a (2017) bakınız. 
pastacılı̆̆ın yapılabilmesi için gereken kriterlerin aranması gerekiyor, bu transkript sistemi gibi bir şey olmall. Örneğin denetimlerde Turizm Otelcilik mezunu olmayan veya meslek yüksek okulu mezunu olmayanlara ceza verilmesi ve mezunların bu alanlarda çalıştırılması gerekiyor. Bundan 8-10 sene önce bunlar konuşuldu ama hayata geçirilemedi. Böyle bir uygulama olsa o zaman pastacılar sıraya girer mezun öğrenciyi işe almak için" (Toprak, yaş 44$)$.

“Öğrencilerin staj süreci emeklilik süresinden sayllmıyor. Bu öğrenciler çok gezmek tozmak istedikleri bir çă̆da gelip çallşlyorlar. Zaten o paraya ihtiyacı olan ögrenciler buraya geliyor. Kesinlikle bu sürenin emekliliğe sayılması gerek" (Ayșe, yaş 41). "Kanunda genellikle eşitlik esastır. Siz bu insanları genç işçi olarak değerlendiriyorsanız, o zaman iş̧̧inin de sahip olduğu haklarl...vermelisiniz. Üretime katkıda bulanan öğrenciler yıpranıyorlar. Universiteyi bitiren insanlar yaklaşık 26 yaşında işe başlıyor. Arada 6-7 yıllık bir fark var. Çocuğun aleyhine neden işletiliyor bu? 2 yıllık hizmet veriyorsa bunun sayılması gerekir. Bu ögrenciler çok yoğun çalışıyor (Bulut, yaş 46). "Bizler de meslek lisesi çıkışlı olduğumuz için çocukları çok daha iyi anlıyoruz. Çok yoğun çalışıp bunun eğitim sayılmasl ve emeklilik süresinde dikkate alınmaması çok hakkaniyete uygun değil", (Bulut, yaş 46) şeklindeki ifadeler aslında staj döneminde ağır bir çalışma yapıldığına ve bu sürenin uzun vadeli sigorta kolları açısından da sayılması gerektiğine dikkat çekmektedir.

“Hemşirelik olsa öneri getireyim ama hemşire yardımcılı̆̆ teknisyenliği olduğu için çocuklar da müfredat dolayısıla çok fazla bir şey öğrenmiyor. Stajda yapabildikleri iş sinırl. Ve zaten bunu gerçek hayatta bir meslek olarak devam ettiremedikleri için yeterli midir değil midir bunu de ğerlendirmek birazcık zor olur. Dolaylsıyla bu yeni bölümlerle SML'de ısrar etmek doğru değil. Ama eski bölümlere dönülse, hemşire, ATT yetiştirilse çok güzel devam edilebilir. Ama şu hali ile devam etmesi çok uygun değil. Eskiden istihdam edilmeleri daha kolaydı. Stajda daha çok işlem yapıp, daha aktif çalışıyorlardı. Şu anda biz girişimsel işlemleri öğretmediğimiz için öğrencilere, stajda biraz etkisiz eleman kalıyorlar. Staj yaptıklart yerlerde girişimsel işlem yapmalarına ilişkin talep oluyor ama biz bu eğitimin müfredatta olmadı̆̆ını buna yetkileri olmadığını söylüyoruz. Öğrencileri de girişimsel işlem yapmama konusunda uyarıyoruz. Stajda tansiyon ölçme, ateş nabız ölçme gibi hafif işleri yapıyorlar. Biraz o süreyi doldurmuş oluyorlar. Evrak dolduruyorlar, hasta getirip götürüyorlar. Rutin işler. Derslerin içeriği ile paralel" (Başak, yaş 36) şeklinde konuşan SML öğretmeni ise eskiden mezun olunduğunda ve çalışma istendiğinde en azından iş piyasasına girebilen öğrenciler varken şimdi unvanın değiştirilmesi ile iş piyasasına girme olanağı dahi olmayan mezunlar yetiştirildiğine dikkat çekmiştir.

\section{Sonuç}

Mesleki eğitimde staj önemli bir işlev görmektedir. Öğrencilerin mesleğe alıştırılması ve mesleğe ilişkin becerilerin geliştirilmesi staj sürecinde gerçekleştirilmekte, ayrıca işletme veya kurumlarda yapılan staj nedeniyle öğrenciler iş piyasasını da tanımaktadırlar. Mesleki eğitim, yapılan yatırım nedeniyle pahalı bir eğitimdir. Mesleki eğitim bir meslek öğrenmek amacıyla verildiğinden ekonomik olarak etkili olabilmesi için mezunların bu mesleği yapmayı istemesi son derece önemlidir. Ancak yapılan çalışma göstermiştir ki meslek liselerini tercih edenlerin büyük bölümü 
bu mesleği yapmak istediği için değil, okul yerleştirme puanı düşük olduğu için bu okullara gelmektedirler. Bu yerleştirme biçimi ekonomik olmadığı gibi, aynı şekilde istemediği bir bölümde okumak zorunda bırakılan öğrenci açısından doğru da değildir. Eğer amaç istihdam için ara eleman yetiştirmek ise bu alanda çalışmayacak kişilere bu eğitimin üstelik de zorla verilmeye çalışılması uygun değildir. Meslek liseleri içinde Turizm ve Otelcilik Meslek Liselerinin durumu farklılaşmaktadır. Bu bölümlere öğrenciler iş bulma, meslek öğrenme amacıyla gelmekte, mezun olduklarında da kolayca iş bulabilmektedirler. Ancak çalışma koşullarının zorluğu ve genellikle işin mevsimlik olması nedeniyle bir süre sonra iş değiştirme istekleri ortaya çıkabilmektedir.

Staj sürecinde en önemli sorun alanlarından birisi öğrencilerin kontrolünün genelde çalışılan kuruma bırakılmasıdır. Öğretmenler belirli aralıklarla okullara gidip kontrol yapmaktadırlar. Staj yapılan kurumda kontrol görevinin yerine getirecek görevlilerin bazen stajyerleri tek başına yapmaması gereken işlerde tek başına bırakması önemli sorunlara neden olabilmektedir. SML'de ilaç uygulamaları, damar yolu açma gibi stajyerlerin yapmaması gereken işlerin kimi zaman da kontrolü sağlanmadan yaptırılması sakıncalıdır. Diğer yandan öğrenciler staj sürecinde "ayak işis" diye tabir edilen işlerde de kullanılmakta, bazı kurumlarda bu işler sadece belli stajyerlere yaptırılarak bir yıldırma politikasına dönüşebilmektedir. Bu durum stajyerlerin bu anlamda da korunması gerektiğine işaret etmektedir. İş riskleri açısından olduğu kadar stajyerlerin psikolojik gelişimleri açsından da bu süreçte yalnız bırakılmamaları gerekmektedir.

Stajyerlerin ücret ve sosyal güvenliklerine ilişkin düzenlemeler mevcuttur. Kısa vadeli sigorta kollarından olan İKMH sigortaları okulları tarafından yapılmakta olup bu kişiler işçi olmadığından uzun vadeli sigorta kollarına tabi değildirler. Ancak özellikle TOML açısından çok uzun süren bir staj ve emek süreci olduğundan hem öğretmenler hem de öğrenciler açısından bu durum eleştirilmekte, bu süredeki çalışmaların emeklilikte dikkate alınması gerektiği belirtilmektedir.

Öğrencilerin büyük çoğunluğunun bu okulları isteyerek seçmemesi istihdam kararlarında da etkili olmakta, öğrencilerin bir bölümü üniversitede başka alanı tercih etmekte ya da başka işlere yönelmektedirler. Asıl amaç bir lise diplomasının alınmasıdır. Sadece diploma almak amacıyla yapılan bu eğitimin pahalı okullar olan meslek liselerinde yapılması uygun değildir. Bu gibi öğrencilerin lise mezunu olması için normal lise eğitimi veren okulların sayısının arttırılması, zorunlu tercihin önüne geçilmesi gerekmektedir.

\section{Kaynakça}

Akçasoy, İ. 2019. Öğrenciler milli eğitim bakanlığı eliyle nasıl işçileştiriliyor. Çalışma Ortamı Dergisi, 161. 23-25.

Aksoy, H.H., 2017. Meslek lisesi öğrencilerinin işletmelerde beceri eğitimi: okul destekli çocuk işçiliği. Mesleki Sağllk ve Güvenlik Dergisi. Ekim 2016-Mart 2017. 62-63. 74-82.

Bınıcı, H. Ve Arı, N. 2004. Mesleki ve teknik eğitimde arayışlar. Gazi Üniversitesi Gazi Eğitim Fakültesi Dergisi, 24 (3). 383-396.

Bolat, Y., 2017. Türkiye'de Mesleki ve Teknik Eğitimin Mevcut Durumu ve Farkl Ülke Karşılaştırmaları. Ankara: PEGEM Akademi.

Çelik, N., Caniklioğlu, N. ve Canbolat, T., 2019. İş Hukuku Dersleri, İstanbul: Beta Basım Yayım Dă̆ıtım. 
Demirdağ, H., Yılmaz, M. ve Gündüz, O., 2018. Bir devlet hastanesinde kesici delici alet yaralanmalarında öğrencilerin yaralanma sıklığı ve kök neden analizi. Ege Üniversitesi Hemşirelik Fakültesi Dergisi, 34 (2), 23-29.

Düzgün, U., Alikoç, S. 2020 (02709). Meslek liseliye uzaktan eğitim sanayi demek. https://www.evrensel.net/haber/412982/meslek-liseliye-uzaktan-eğitisanayi-demek.

Erder, S. ve Lordoğlu K. 1993. Geleneksel Çıraklıktan Çocuk Emeğine Bir Alan Araştırması. İstanbul: Friedrich Ebert Vakfi.

Gönç Savran, T., 2012. Nicel ve nitel araştırmalarda kullanılan araştırma teknikleri. Sosyolojide Araştırma Yöntem ve Teknikleri. Ed. T. Gönç Savran. Eskişehir: Anadolu Üniversitesi.

Kablay, S., 2018. Yaşama verilen değerin bileşik göstergesi çerçevesinde ülkemizdeki çalışma hakkı açısından durum. Gürhan Fişek'in İzinde Ortak Emek Ortak Eylem. Ankara: Siyasal Kitabevi. 451-478.

Kablay, S., 2019. Stajyer mi işçi mi? Çalışma Ortamı Dergisi, 162, 15-19.

Kablay, S., 2021. Covid-19 stajyerlere uğramaz mı? Çalışma Ortamı Dergisi, 167, 21-26.

Mert, İ. S., 2018. Hemşire ve stajyer hemşirelerde en fazla stres yaratan olayların nitel araştırma yöntemiyle incelenmesi. Elektronik Sosyal Bilimler Dergisi, 17 (67), 1043-1059.

Pınar, E. 2017. Mesleki eğitim politikalarına devlet-sermaye ilişkileri açısından bakmak. Eğitim Bilim Toplum, 15 (58). 38-59.

Polat, E., Çalışkan, S. ve Met, Ö. L., 2016. Çalışma yeri tercihlerinde işletmelerin iş etiği uygulamalarının önem derecesi: ortaöğretim düzeyinde turizm eğitimi alan öğrenciler üzerine bir araştırma. Balıkesir University The Journal of Social Institude. 19 (36-1). 525543.

T.C. Millî Eğitim Bakanlığı. 2018. Türkiye'de Mesleki ve Teknik Eğitimin Görünümü, Eğitim Analiz ve Değerlendirme Raporları Serisi. Eğitim ve Değerlendirme Raporları Serisi No: 1

T.C. Millî Eğitim Bakanlığı. 2020. Covid-19 Salgını Sürecinde Mesleki ve Teknik Eğitim.

Süzek, S., 2019. İş Hukuku, İstanbul: Beta Basım Yayım Dağııım.

Yağc1, K., Efendi, M. Ve Akçay, S. 2021. Satajyerler; seyahat işletmesi sahipleri ve yöneticileri bakış açısıyla. Türk Turizm Araştırmaları Dergisi, 3 (4), 1244-1259.

\section{Yasalar}

3308 Sayılı Mesleki Eğitim Kanunu: 19/06/1986 tarih ve 19199 sayılı Resmî Gazete.

4857 Sayılı İş Kanunu: 10/06/2003 tarih ve 25134 sayılı Resmî Gazete.

5510 sayılı Sosyal Sigortalar ve Genel Sağlık Sigortası Kanunu: 16/06/2006 tarih ve 26200 sayılı Resmî Gazete.

6098 Sayılı Türk Borçlar Kanunu: 04/02/2011 tarih ve 27836 sayılı Resmî Gazete.

6331 Sayılı İş Sağlığı ve Güvenliği Kanunu: 30/06/2012 tarih ve 28339 sayılı Resmî Gazete. 